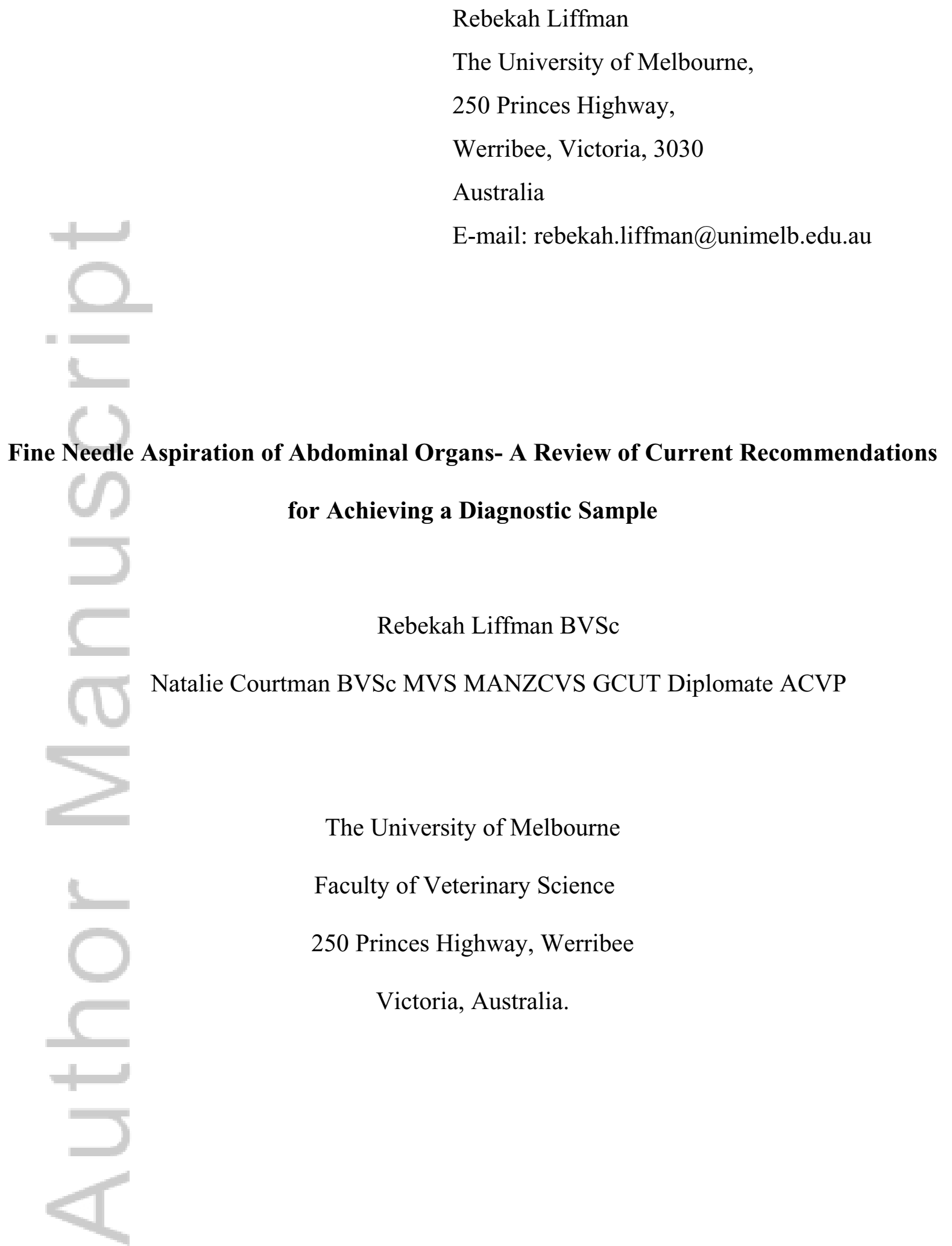

This is the author manuscript accepted for publication and has undergone full peer review but has not been through the copyediting, typesetting, pagination and proofreading process, which may lead to differences between this version and the Version of Record. Please cite this article as doi: 10.1111/jsap.12709

This article is protected by copyright. All rights reserved. 


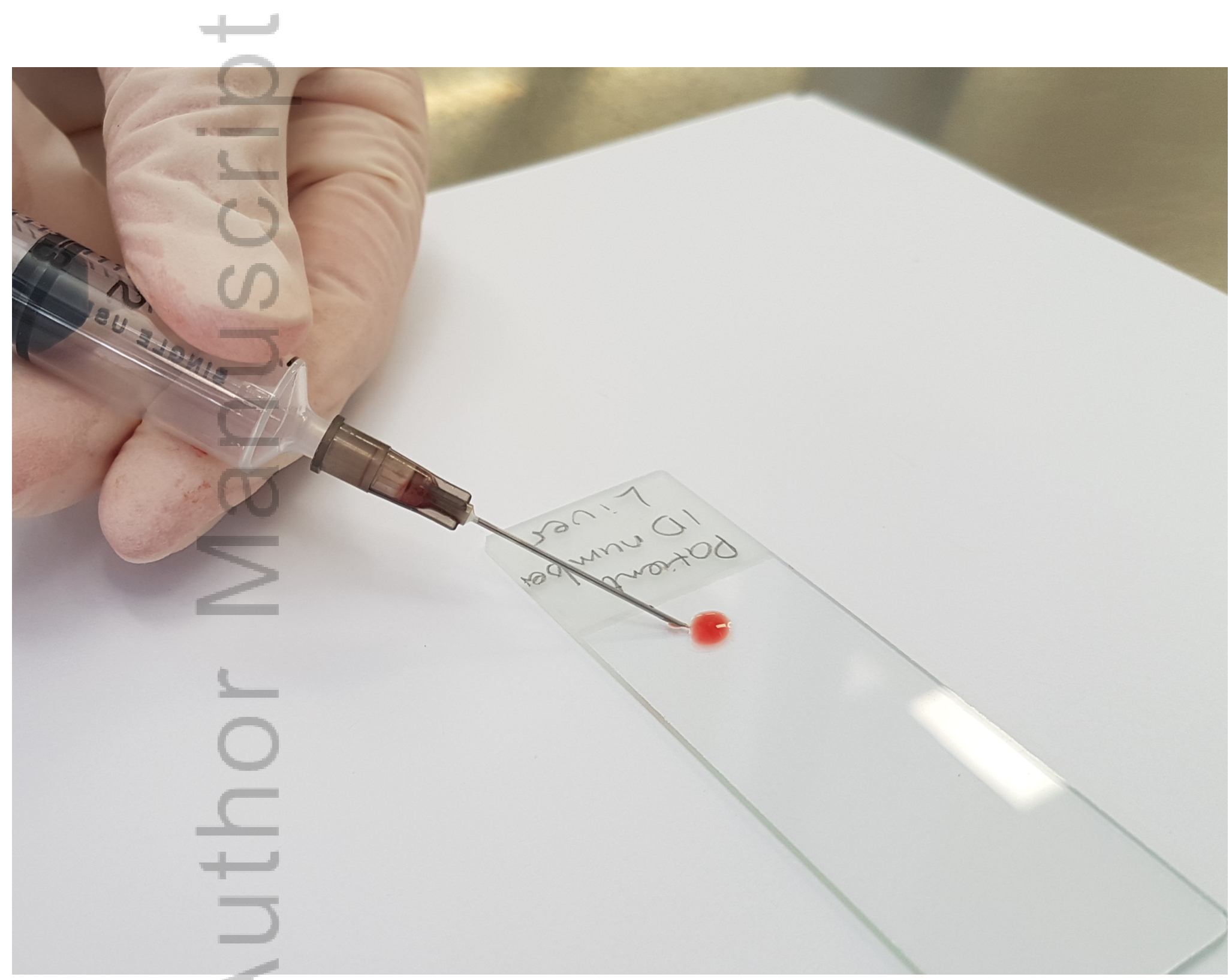

Figure 1.png

This article is protected by copyright. All rights reserved. 


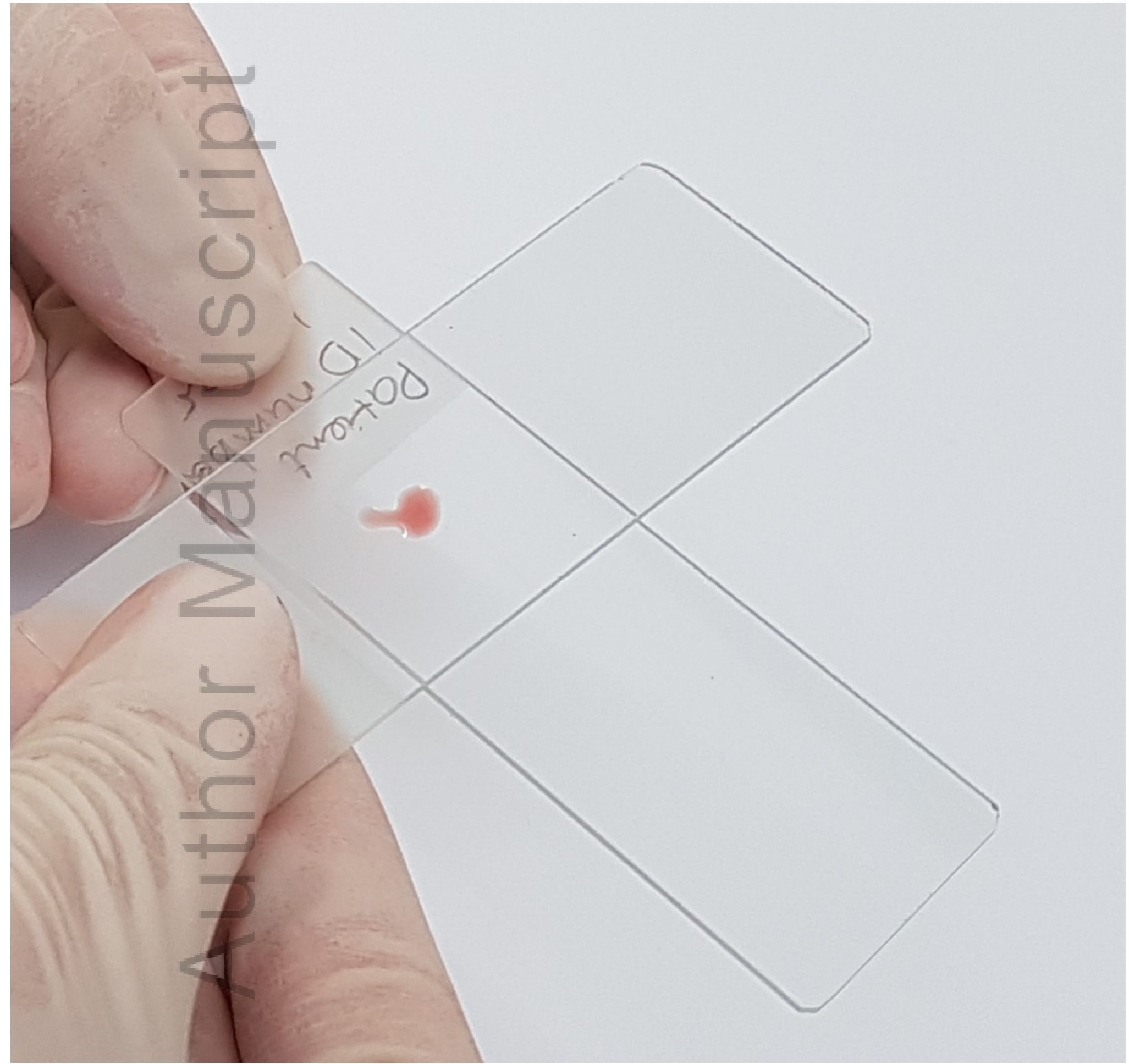

Figure 2.png

This article is protected by copyright. All rights reserved. 


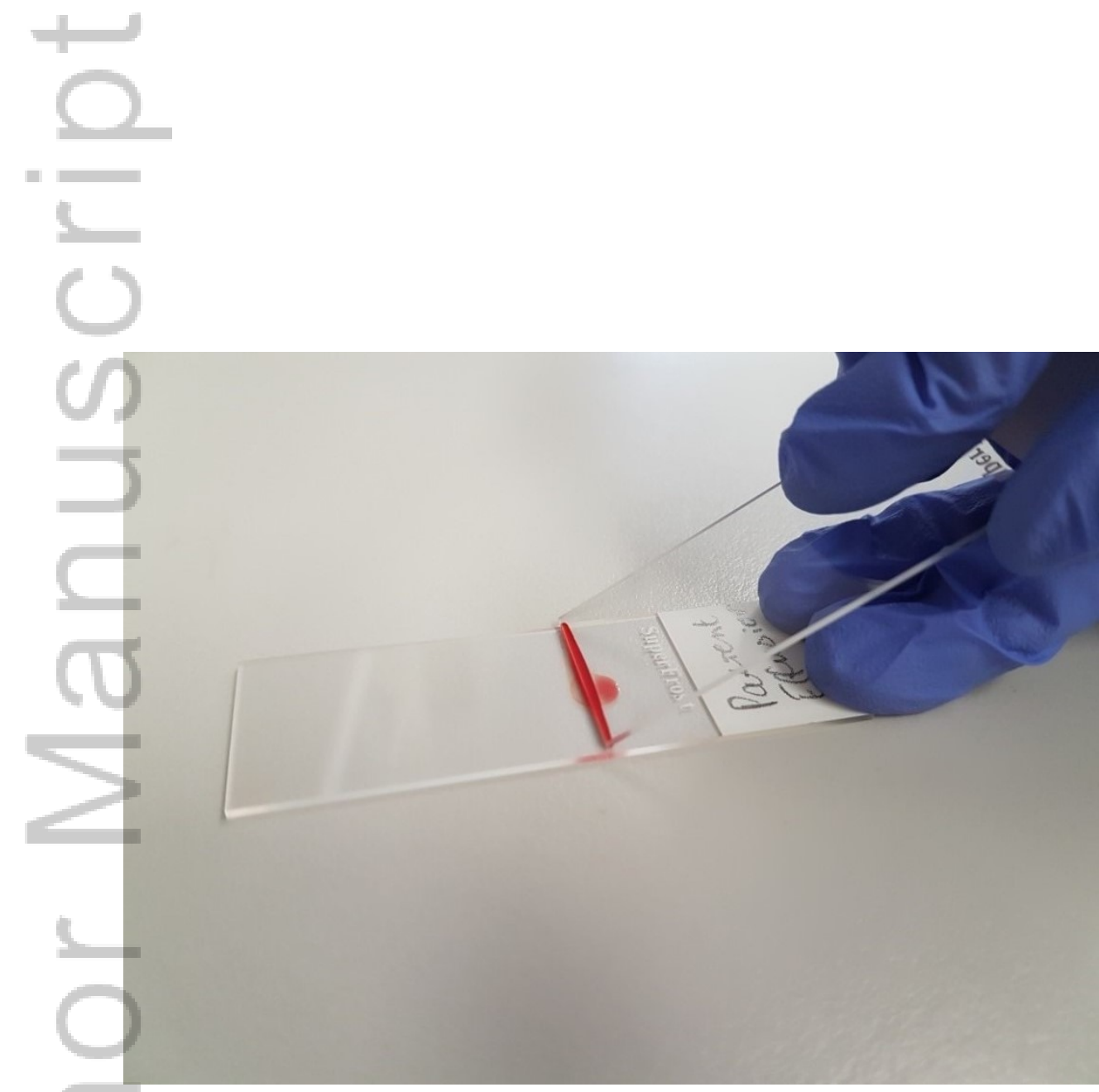

Figure 3.jpg

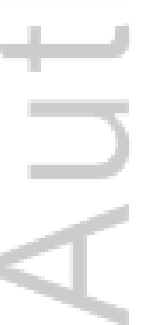

This article is protected by copyright. All rights reserved. 


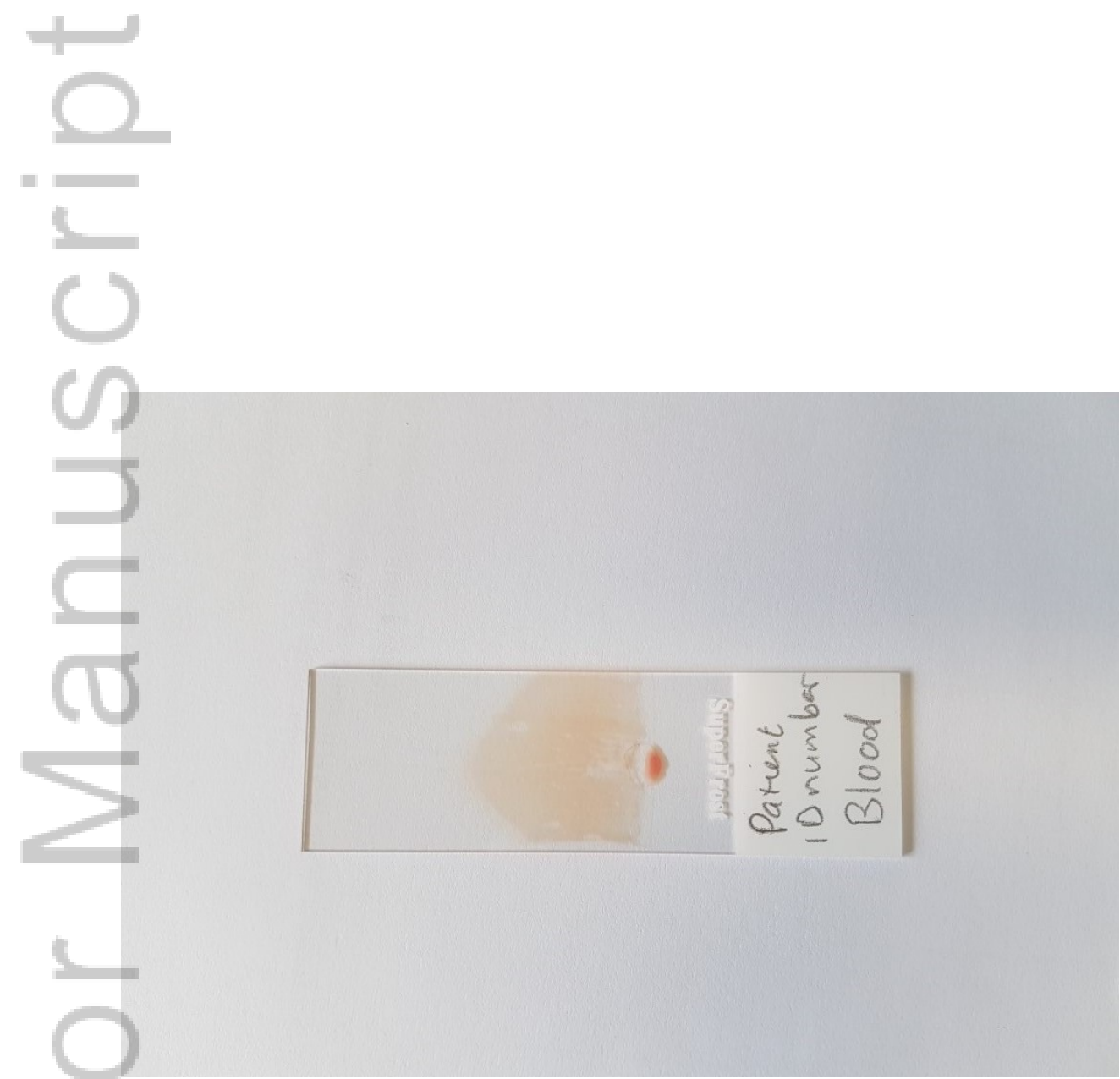

Figure 4.jpg

This article is protected by copyright. All rights reserved. 


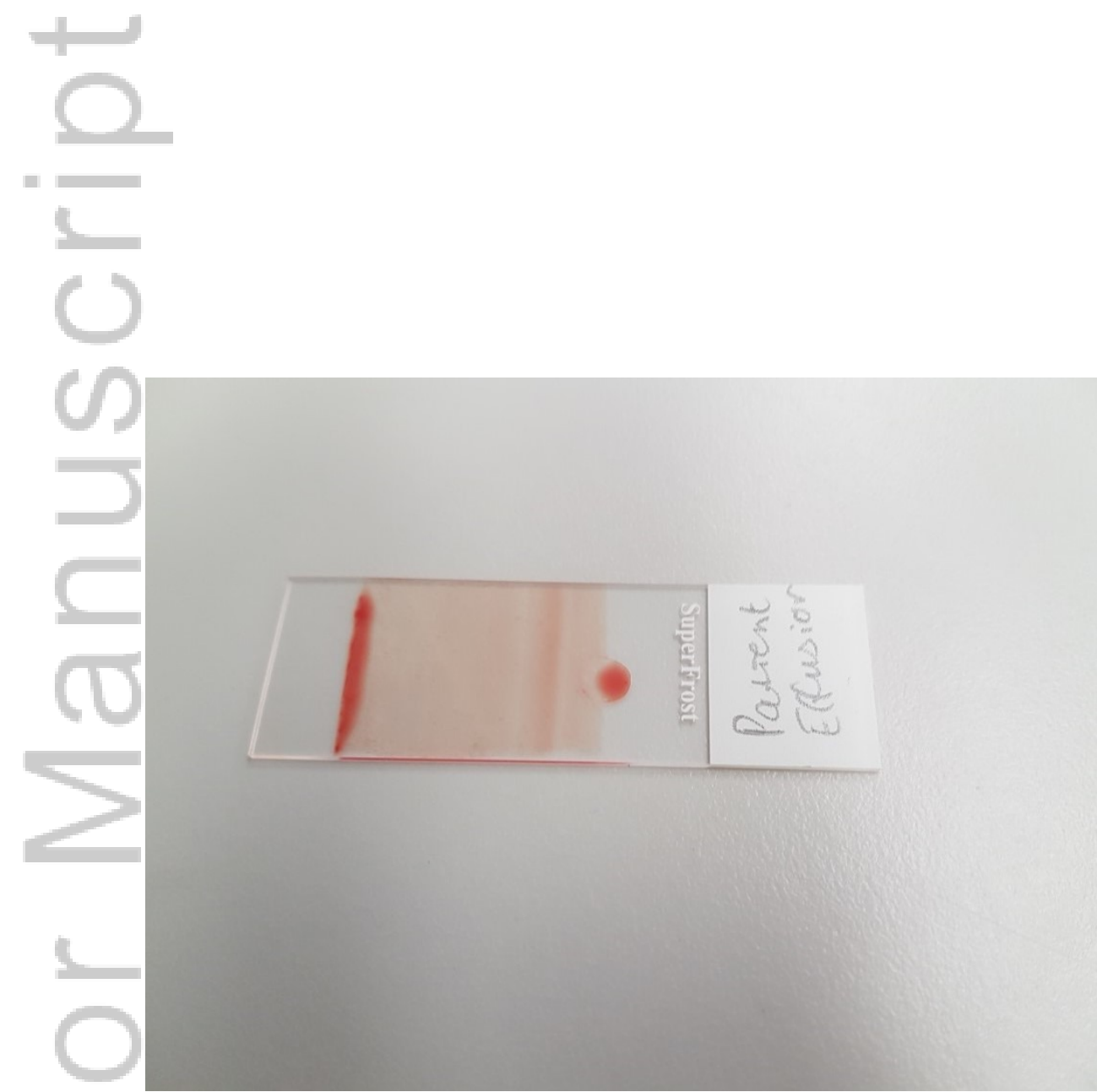

Figure 5.jpg

This article is protected by copyright. All rights reserved. 


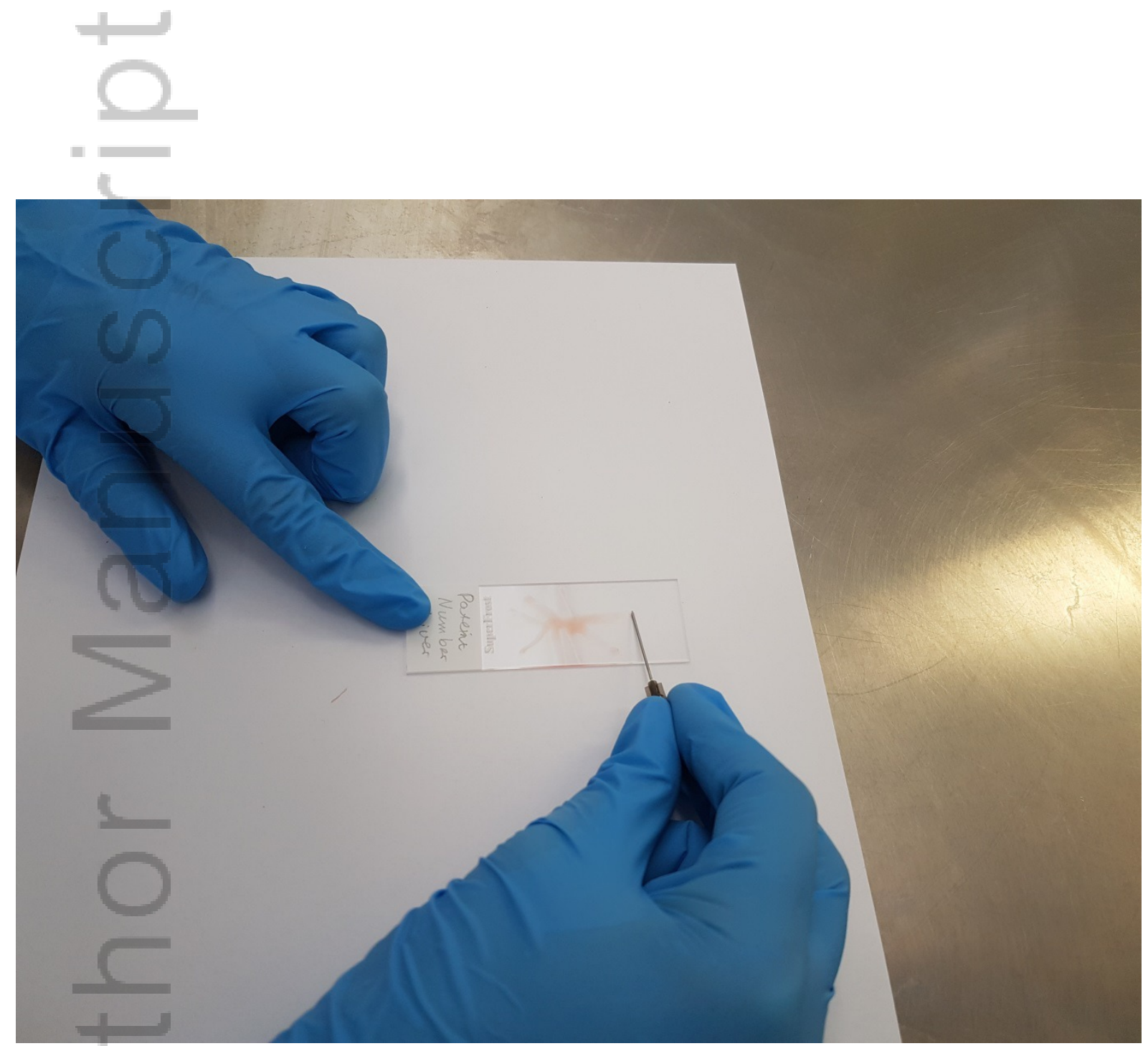

Figure 6.jpg

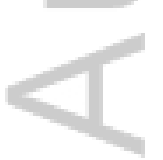

This article is protected by copyright. All rights reserved. 

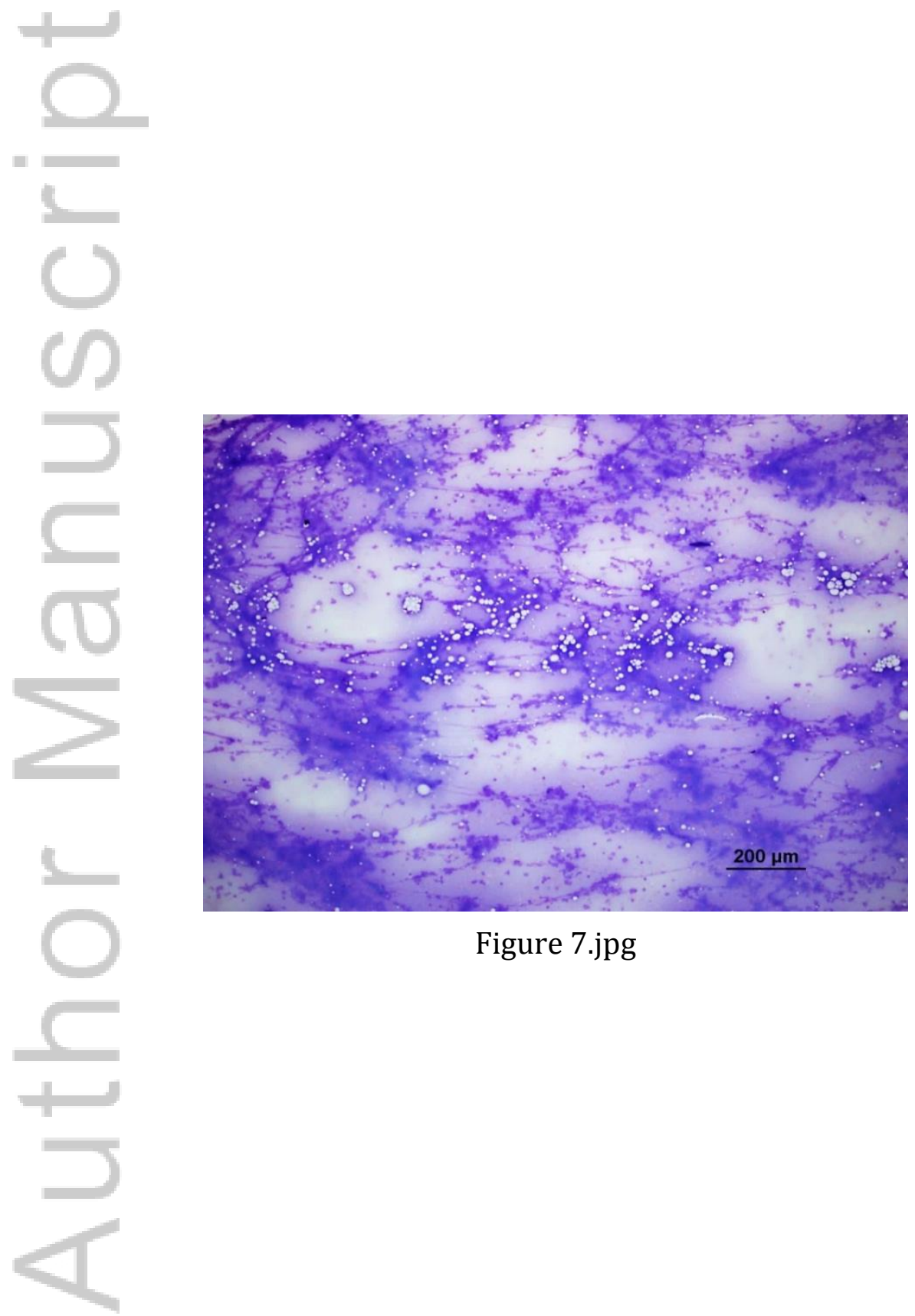

Figure 7.jpg

This article is protected by copyright. All rights reserved. 


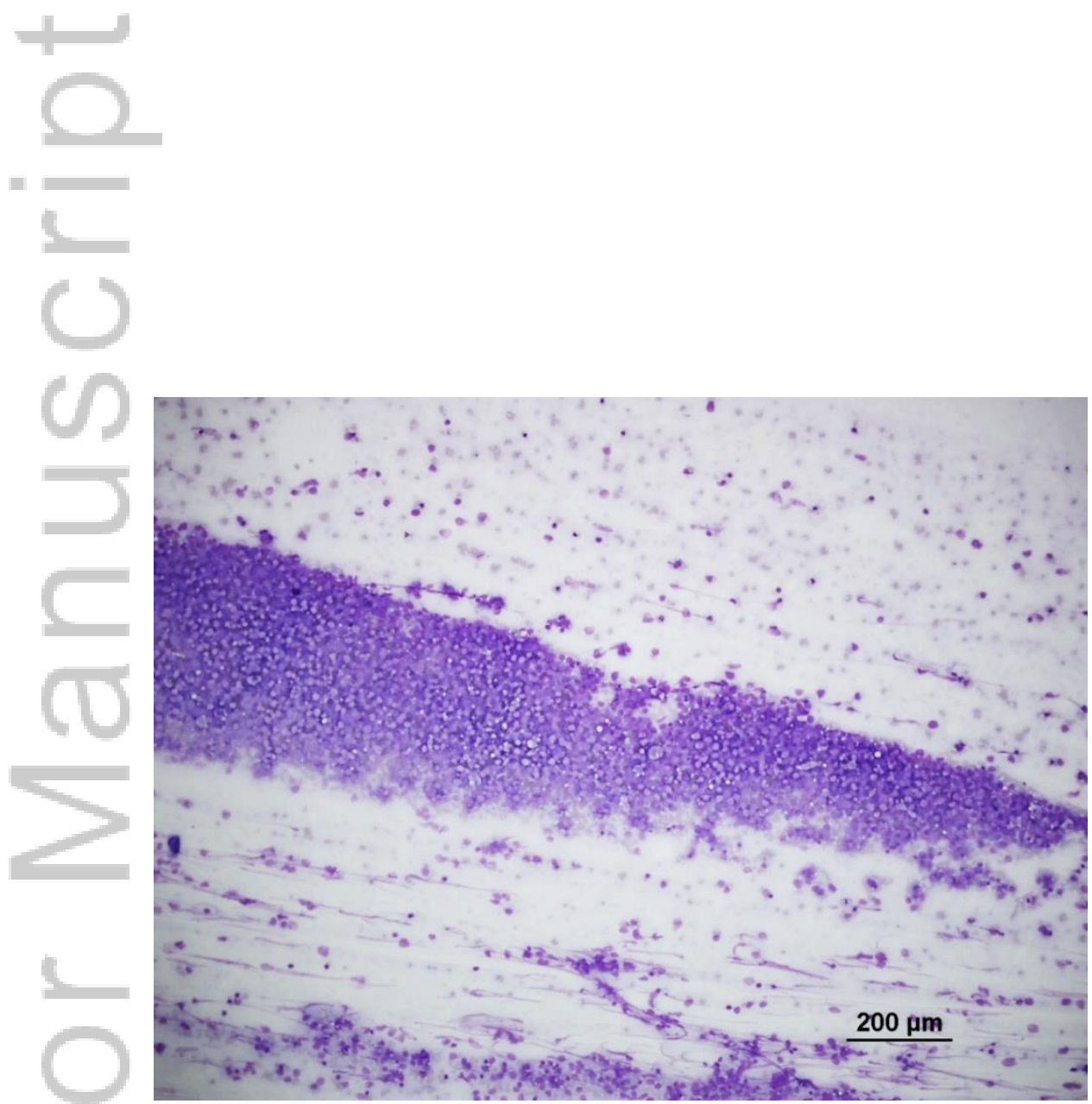

Figure 8.jpg

This article is protected by copyright. All rights reserved. 


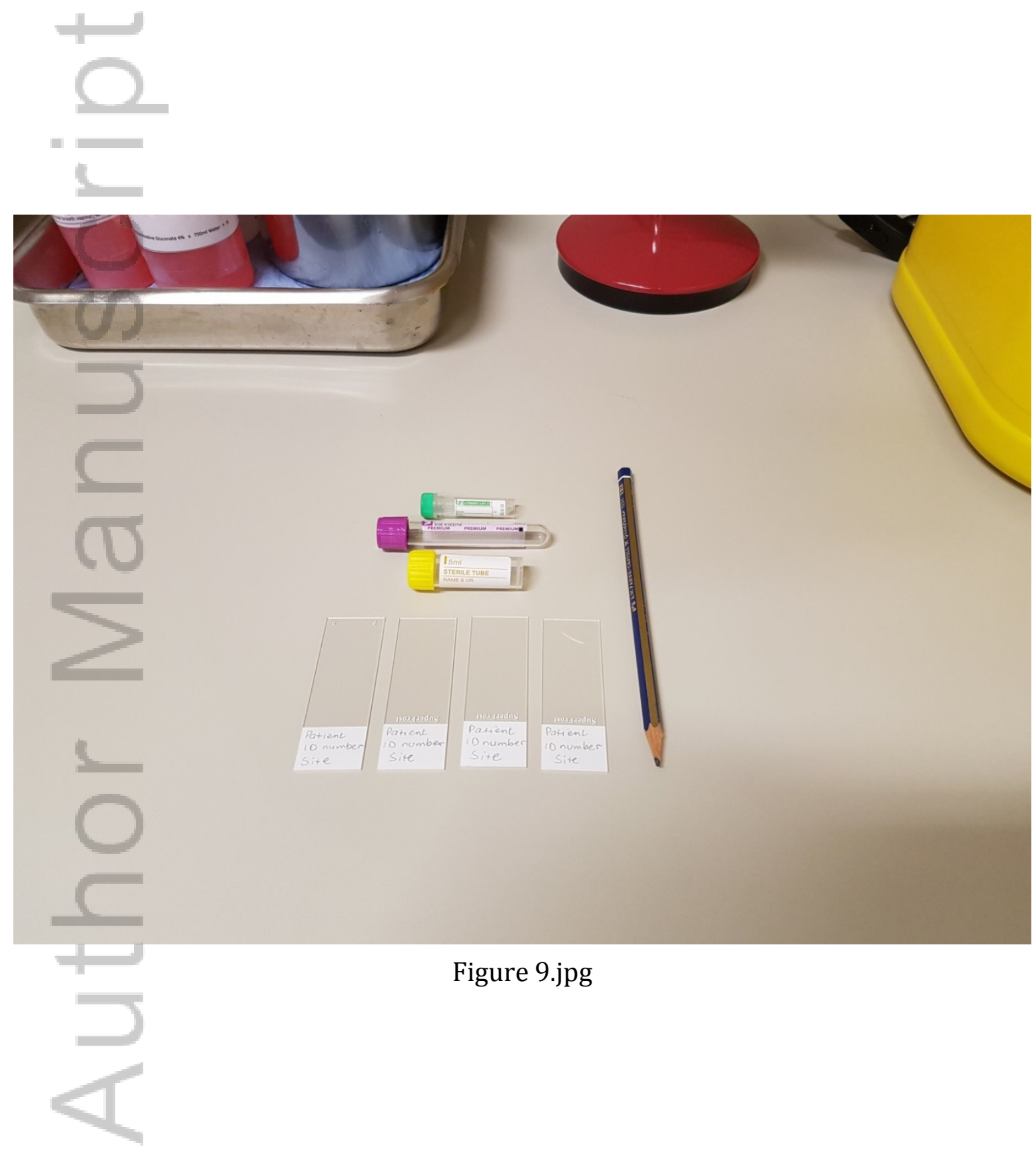

This article is protected by copyright. All rights reserved. 


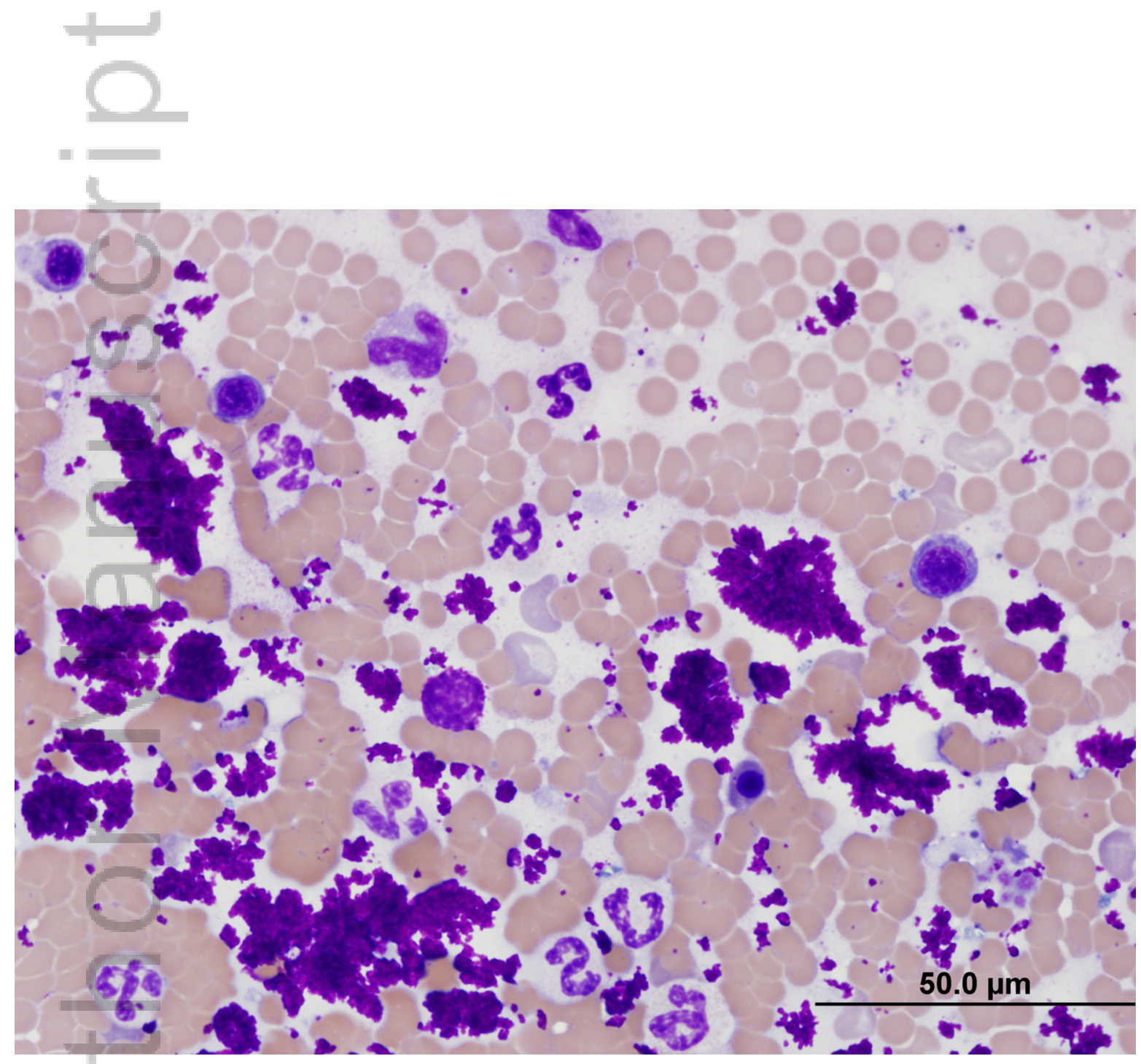

$+5$

Figure 10.jpg 


\title{
Fine Needle Aspiration of Abdominal Organs- A Review of Current Recommendations for Achieving a Diagnostic Sample
}

\begin{abstract}
With the improved accessibility to ultrasound, fine needle aspiration of abdominal organs is now performed frequently in many veterinary practices. Despite this, there are many 'unknowns' as to the best method to produce a high-quality sample.

This report begins by highlighting recent literature on the risks and benefits of abdominal fine needle aspiration. It follows with recommendations as to the equipment and method best suited to the procedure, including needle and syringe size, and aspiration versus nonaspiration techniques. Various smear preparations and laboratory submission requirements are also discussed. The final aspect of the review more specifically discusses fine needle aspiration of specific abdominal organs; the liver, kidney, spleen, pancreas, urinary bladder, prostate and abdominal lymph nodes.
\end{abstract}

Keywords: 'Fine Needle Aspiration',' Imaging-Ultrasound', 'Clinical Pathology', 'Cytology,

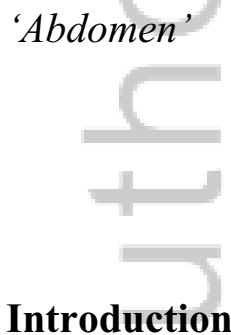

'Fine needle aspiration' (FNA) is a method used for the aspiration of tissue cells via the introduction of a small-gauge needle into a lesion. The samples obtained from FNA are then used to prepare a specimen that can be analysed by various methods, such as microscopy. If successful, these results can then be used to obtain a definitive diagnosis, to guide additional 
testing or to rule in or out specific diseases. There is rarely a need for general anaesthesia during the procedure and the small gauge of the needle seldom leads to clinical complications.

With the advent of advanced imaging modalities such as ultrasound, fluoroscopy, and computed tomography, sampling and the diagnosis of deep-seated lesions within the abdomen are now possible without the requirement for surgical exploratory laparotomy. Ultrasound is readily accessible in many general practice clinics, and can be used to obtain abdominal FNA samples. Ultrasound-guided sampling has several advantages over blind aspiration, including the direct and constant visibility of the needle and target organ, enhancing the accessibility of deep-seated lesions, and increasing accuracy and safety when compared with blind aspiration ( Grant et al., 1983, Hager et al., 1985, Babb and Jackman, 1989, Pujani et al., 2016).

Given the many benefits of FNA, determining a protocol that will provide the highest chance of obtaining a diagnosis is extremely important. Currently controversies exist in both human and veterinary literature about the influence of factors such as needle size, aspiration versus non-aspiration techniques and appropriate sample preparation. The aim of this report is to examine published literature on such controversies, and present recommendations for successful FNA sampling of abdominal organs in veterinary practice.

\section{Risk versus benefit of FNA}

In humans, the benefits of performing ultrasound-guided FNA of abdominal lesions have been evaluated. A study by Gani et al. (2011) of 67 cases concluded that the FNA procedure played a significant role in obtaining a diagnosis in the majority of patients, with no major clinical complications observed. In the veterinary world, the success of obtaining a diagnosis using FNA for abdominal organs is variable. Sampling of abdominal lesions is not performed 
with the same frequency as FNA in other sites, such as cutaneous lesions. At our institution, which receives both first opinion and referral practice submissions, 922 FNA's from tissue samples were submitted in 2016, and of these, 429 (47\%) samples were obtained from abdominal organs (unpublished data). Interestingly, Skeldon and Dewhurst (2009) looked at 945 cytology samples submitted to their laboratory, and found only $37(3.9 \%)$ samples were obtained from abdominal organs. This difference may reflect the different proportions of submissions received from primary care and referral practices, as the vast majority of veterinarians that submitted to the latter were reported to work in a primary care practice.

Diagnosis rates from abdominal organs have been found to be much lower than other sites, showing a definitive diagnosis in only $2 / 37$ cases, with 27 samples described as 'moderately clinically useful' or 'clinically useful' (Skeldon and Dewhurst, 2009). Other studies show more promising results; Léveillé et al. (1993) found FNA specimens of abdominal organs correlated with the final diagnosis made during surgical exploration or necropsy in 59/70 of samples. When categorising disease according to the 2 criteria of 'inflammatory' or 'neoplastic', Bonfanti et al. (2004) observed that FNA showed an $89 \%$ success rate in differentiating inflammatory from neoplastic disease based on 132 samples from abdominal lesions. Importantly, malignancy was correctly detected in all malignant neoplasia.

The discrepancy in these results may reflect pathologist experience in cytological interpretation, differences in case load, and differences in definition of agreement. Higher success rates may also be seen in referral institutions where clinicians are generally more practised at obtaining cytological samples from abdominal viscera compared with general practitioners. However, even studies conducted at referral centres may show poor diagnostic accuracy. Cohen et al. (2003) examined 29 liver and splenic FNA samples collected at a veterinary referral institution. FNA and impression smear techniques were used and compared with histopathology or post mortem examination. The number of cytological 
samples that attained 'complete or partial agreement' with other methods was found to account for only $34 \%$ of samples. The authors also reported that impression smears had a higher level of agreement than samples obtained from FNA.

Abdominal FNA has a very low clinical complication rate, with a minor complication rate of $3.9 \%$ and no major complications observed in a study of 102 human patients with abdominal tumours (Binek et al., 1995). Penetrating abdominal viscera with 20-23G needles has been shown to produce minimal complications, with large-scale human studies reporting a total complication rate of $0.55 \%$, and only 1 death resulting from abdominal FNA reported in 11,700 cases (Livraghi et al., 1983).

Similarly, in veterinary studies, medical records for ultrasound-guided FNA have been reviewed for procedural complications. Complications did not develop at all after FNAs in many studies, whilst other studies reported rare mild complications, such as pain, small haematomas, minimal bleeding from the local site, and haematuria (Hager et al. 1985, O'Keefe and Couto 1987, Léveillé et al. 1993, Bonfanti et al. 2004) . Two deaths were reported in each of 2 abstract reports on 307 feline liver FNA's, and 600 canine liver FNA's (Menard and Papageorges 1996, Papageorges 1996).

The safety of using an $18 \mathrm{G}$ needle to obtain core biopsies of abdominal organs has been evaluated in dogs and cats with coagulation deficiencies in a study by Bigge et al. (2001). Findings suggested that the procedure should be delayed if there is moderate or marked thrombocytopenia because significant bleeding complications occurred in $22 \%$ of dogs and $50 \%$ of cats with platelet counts $<80 \times 10^{9} / \mathrm{L}$ (Bigge et al., 2001). However, this may not pertain to FNA, because tissue core biopsies tend to incur greater risk of haemorrhage (Léveillé et al., 1993, Bigge et al., 2001, Vaden et al., 2005). When 56 human patients with mild thrombocytopenia $\left(70-100 \times 10^{9} / \mathrm{L}\right)$ underwent splenic FNA, no correlation between 
thrombocytopenia and post-procedural complications was observed, with only 3 cases showing complications (Civardi et al., 2001a). In pigs treated with warfarin, there was no significant increase in bleeding compared to untreated pigs during renal and hepatic FNA (Gazelle et al., 1992).

Another frequently discussed complication of FNA is needle tract tumour implantation. In humans, it is considered a rare complication of FNA, occurring with an estimated frequency of $0.009 \%$, with pancreatic neoplasia associated with most of these events (Smith, 1991). In both humans and animals, pancreatic carcinoma is considered highly malignant, with most cases of needle tract seeding diagnosed within 2-6 months of the procedure.

In animals, rare cases of suspected tumour tract implantation following abdominal FNA have been reported; there is a single case report involving a case of renal carcinoma (Livet et al., 2016), but the majority of suspected needle tract implantation were suggestive of urothelial cell carcinoma (UCC) implantation in the abdominal wall following FNA of the bladder, urethra or prostate (Nyland et al., 2002, Higuchi et al., 2013, Vignoli et al., 2007, Wilson et al., 2007). UCC's (previously known as transitional cell carcinomas) are highly malignant, and so the apparent higher risk of implantation with this tumour may be a reflection of its aggressive nature (Norris et al., 1992, Meuten, 2008, Higuchi et al., 2013).

We share the opinion that in the majority of cases, the low risk of implantation is outweighed by the benefits of obtaining a minimally-invasive diagnosis, although these risks should be discussed with the owner before proceeding. 


\section{Performing a fine-needle aspirate}

Before performing an abdominal FNA, ultrasound gel should be carefully removed from the patient, because the gel is observed microscopically as granular magenta debris (see Figure 10). This can mimic necrotic tissue and mast cell granules, and can also lead to cell lysis and swelling that can hinder cytological interpretation (Raskin and Meyer, 2015).

\section{Needle size}

The term 'fine-needle aspiration' is reserved for needles smaller than $20 \mathrm{G}$, or with an outer diameter of $<1.0 \mathrm{~mm}$ (Livraghi et al., 1983, de Rycke et al., 1999). Disadvantages of these smaller gauge needles are the flexibility which can cause slight bending during sampling of deep-seated lesions, and the small diameter of the needle which makes them more difficult to see during ultrasonography (Hager et al., 1985, de Rycke et al., 1999).

In veterinary practice, FNA is most commonly performed using a 20 - to $27 \mathrm{G}$ needle and a 6to 12-mL syringe (Wypij, 2011). Obtaining a diagnostic FNA from abdominal organs in smaller animals can generally be accomplished with a $2.5-3.8 \mathrm{~cm}$ needle, whereas a $6.3-8.9 \mathrm{~cm}$ spinal needle may be required for deeper internal organs or for larger animals (Raskin and Meyer, 2015).

There have been many studies that aimed to determine the optimum needle gauge for FNA. In humans, $23 \mathrm{G}$ needles are considered less painful than $21 \mathrm{G}$ needles for sampling both head and neck (Brennan et al., 2007) and breast lesions (Daltrey and Kissin, 2000). In a study of 100 people, there was no significant difference between needle size and diagnostic yield (Brennan et al., 2007). With extrapolation to veterinary medicine, the results of these studies indicate that a smaller needle gauge should be considered if the patient is likely to experience discomfort (i.e. is not sedated with an analgesic). 
A human study by Dähnert et al. (1992) compared 4 different types of needles, all of similar gauge, but with a slightly different internal diameter. The 20G trephine, 20G slotted, 19.5G cut biopsy and 20G spinal needle were compared, using a total of 551 needles for abdominal organ tissue aspiration. Although the needles were of similar gauge, the internal diameter did vary slightly (by $\mathrm{d} 0.2 \mathrm{~mm}$ ). Interestingly, the needle with the largest internal diameter (cut biopsy needle) yielded the largest proportion of specimens that were considered insufficient for evaluation. These results support the previous study findings that larger gauge needles do not necessarily increase the likelihood of obtaining a diagnostic sample. (Dähnert et al., 1992)

However, other studies have refuted this, instead suggesting that larger needle diameter produced greater tissue yields (Pagani, 1983, Haseler et al., 2011). Pagani (1983) found that, in human patients, $18 \mathrm{G}$ needles retrieved a larger amount of tissue than $22 \mathrm{G}$ needles when used in the aspiration of hepatic lesions using CT-guidance, and thus allowed evaluation of a greater number of cells. It should be noted that CT-guided FNA is rarely used in veterinary patients for abdominal organ aspiration and is usually only reserved for lesions inaccessible by ultrasound. In Pegani's study, diagnostic accuracy was $98 \%$ when using the $18 \mathrm{G}$ needle, compared to only $84 \%$ with the $22 \mathrm{G}$ needle.

The correlation between increased blood loss and needle size has been evaluated in pigs. Larger needles did produce more bleeding but the differences were minimal except when comparing needles d16G with needles e 18G. In the kidney, no significant difference was noted between the use of 18G-, 20G-, and 22G needles (Gazelle et al., 1992).

\section{Aspiration technique}

Ever since the non-aspiration technique was first described by Zajdela et al. (1986), many studies have evaluated aspiration versus non-aspiration techniques in an attempt to come to a consensus about which is preferable. A major advantage of the non-aspiration technique is 
reduced blood contamination when sampling highly vascular tissues such as the spleen (LeBlanc et al., 2009), kidney and liver (Savage et al., 1995, Raskin and Meyer, 2015) . Nonaspiration has been found to have similar or greater sensitivity to that of aspiration for a variety of tissues, including the spleen and abdominal lymph nodes (Wallace et al., 2001, Sajeev and Siddaraju, 2009, LeBlanc et al., 2009, Sigstad et al., 2004, Savage et al., 1995, Menard and Papageorges, 1995, Jahromi et al., 2015). In contrast, other studies have shown an increased diagnostic yield in the liver (Haseler et al., 2011) and pancreas (Kinney et al., 1993) when using aspiration as opposed to non-aspiration techniques. In a study by Savage et al. (1995) that examined 95 abdominal FNA sites in humans, more diagnostic specimens were achieved when using aspiration in the pancreas and kidney, although non-aspiration showed greater diagnostic capabilities when sampling abdominal lymph nodes and pelvis masses.

If the aspiration technique is preferred, optimal syringe size should be considered. One must take into account technical control when using different sized syringes, as well as the ideal aspiration force. Haseler et al. (2011) found that syringe size has a potent effect on control of the needle, with experienced operators showing improved control when using smaller syringes than larger ones. Larger syringes limited the ability to maximally retract the plunger and create the full vacuum potential. When comparing the force capabilities of different sized syringes, each point generated identical vacuum at the same volume displacement of the plunger. This has important implications in practice; if the plunger of the $20 \mathrm{~mL}$ syringe is used to only displace the plunger to the $5 \mathrm{~mL}$ mark, there is an inherent disadvantage to using the $20 \mathrm{~mL}$ syringe compared to the $5 \mathrm{~mL}$ syringe, as the smaller device will enable improved technical control. Some radiologists routinely attach an IV extension set to the needle, in order to allow freedom of movement during aspiration (Menard and Papageorges, 1995). 
When using the aspiration technique, recommendations regarding the degree of suction to apply during FNA are quite variable, with reports of 'a few' $\mathrm{mL}$ of vacuum (Raskin and Meyer, 2015), or one-half to three-fourths of the syringe (Barger, 2014).

Once the needle has entered the lesion, it should be moved forward and backward 3-4 times in short, rapid strokes in a swift cutting motion (Raskin and Meyer, 2015). Titoria et al. (2010) found that directing the needle in a multiplane fashion yields significantly more tissue than single-plane yields. Using a 'coring' motion does not appear to influence tissue yield, as the sample is acquired by the cutting action of the needle and is maintained in the needle core by forward motion and capillary tension (Titoria et al., 2010).

A definitive diagnosis was obtained in $61 \%$ of human abdominal FNA cases with the first needle pass, with a further increase of $21 \%$ with the second FNA attempt using a new needle, 8\% with the third FNA attempt, and 6\% with the fourth FNA attempt (Dähnert et al., 1992). Therefore, slides from at least 4 or 5 aspirates should be submitted from each lesion sampled. If a necrotic centre is suspected, samples should also be obtained from the margin of the lesion (Raskin and Meyer, 2015). One or 2 slides should be stained and briefly examined to ensure they are adequately cellular before submitting to the referral laboratory (Skeldon and Dewhurst, 2009, Wypij, 2011). This allows for repeat FNA to be performed if the samples are inadequate (Barger, 2014). If the smears appear excessively thick or very little material is apparent, additional slides should be made.

\section{Specimen Preparation}

Once the needle has been removed from the tissue, smears should be made without delay. A delay can lead to blood clotting within the hub, which makes expression of the specimen 
difficult (McGrath, 2008), and can also affect the ability to smear the material, which may lead to poor cell preservation.

\section{Smears}

Several smear preparations have been described in the literature, although there is scope for more case control studies. 'Shooting' the contents from a distance is not recommended as this will result in many small drops that tend to dry out before they can be spread. Instead, the plunger should be rapidly advanced to express a small droplet of the sample $(2-3 \mathrm{~mm}$ diameter) onto the slide. This should be performed quickly to prevent drying of the sample (Menard and Papageorges, 1995). (Figure 1)

There are several methods described to smear the aspirated material, with the aim being to achieve a monolayer of well-preserved cells. The following are descriptions of the 'squash prep', the 'blood smear', the 'line smear', and the 'starfish prep'.

1. The 'squash prep' is used for semi-solid material. The 'spreader' slide is placed on the specimen at right angles. The drop of material should spread only from the weight of the top slide, and downward pressure is not required. As the specimen is spreading, the top slide is gently drawn over the length of the first (Lastra, 2015). (Figure 2)

Disadvantages of the squash prep include the potential for the smear to be too thick for diagnosis, and the slight downward pressure can lead to squashing of the sample, causing cell rupture and a non-diagnostic preparation (Barger, 2014).

2. The 'blood smear' technique is recommended for bloody or serous samples (Barger, 2014). The short edge of the slide is placed onto the flat surface of the sample slide. The spreader slide is then tilted to an angle of 45 degrees and pulled backwards about one-third of the way into the material. (Figure 3) 
Once the material has dispersed along the spreader slide, the slide is smoothly slid forward in one rapid motion. The finished smear should have a feather-shaped area which is indicative of a monolayer.

\section{(Figure 4)}

3. The 'line smear' is recommended for serous samples with low cellularity (Barger, 2014). This is very similar to the blood smear technique, except that the spreader slide is abruptly stopped and lifted off the specimen slide approximately $1 \mathrm{~cm}$ before reaching the end of the slide. (Figure 5)

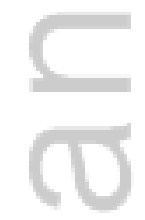

4. 'Starfish preps' involve spreading the sample peripherally with a needle tip (Sirois, 2012). Many areas of the smear will be too thick for evaluation, and therefore this method is not frequently used and the authors do not recommend this technique. (Figure 6)

\section{Staining}

Heat fixing before staining is not recommended because it is likely to damage cell morphology (Raskin, 1000). Air-drying is the preferred method. Baig et al. (2006) found that the use of a small hand-held fan can reduce the average time needed for air-drying, and does not cause a reduction in stain quality.

Papanicolaou stains are commonly used in human laboratories, and Romanowsky variants are used in most veterinary laboratories, whilst Diff Quik (a modified Romanowsky stain) is frequently used in clinics (Jörundsson et al., 1999, Silverman and Frable, 1990). 
Romanowsky stains have advantages over Papanicolaou stains including excellent depiction of cytoplasmic detail and superior visbility of bacteria, mucin and colloid, whilst limitations of Romanowsky stains include reduced nuclear and nucleolar detail (Jörundsson et al., 1999). Mast cell granules are not always easily seen when using Diff Quik (Jackson et al., 2013).

Recommendations for Diff Quik staining techniques in the literature suggest at least two minutes or 20 rapid dips in alcohol, one minute or 20 rapid dips in stain I, and 45 seconds or 20 rapid dips in stain II (Jörundsson et al., 1999). In the authors' experiences, this recommendation seems excessive, and may lead to an over-stained specimen, which could hinder diagnosis. The method can be adjusted based on the thickness of the tissue and freshness of the stain, but 6 to 8 1-second dips in stain I and II is usually sufficient. Dipping rather than passive immersion enhances staining and reduces the time required in solution (Jörundsson et al., 1999). After staining, the slide should be gently rinsed for 20 seconds using room temperature water and be allowed to dry in a vertical position (Raskin and Meyer, 2015). Avoid blotting as this can lead to removal of cell material.

The specimen should be examined with the $10 \mathrm{x}$ or $20 \mathrm{x}$ objective to assess staining quality and cell exfoliation/preservation, before further examination or submission for pathologist evaluation (Raskin and Meyer, 2015) (See Figures 7 and 8). If staining is insufficient, slides can be stained for longer in the Diff Quik solutions if immersion oil has not yet been applied to the slides.

The importance of assessing slides before submission for a pathologist's evaluation cannot be overemphasised. In one survey of 74 predominantly general practitioner veterinarians, Skeldon and Dewhurst (2009) found that participants indicated that on average $51 \%$ of cytological samples were sent to an external laboratory without previous in-house evaluation. Of the total submitted, $19 \%$ of samples were considered to be of unacceptable quality to 
obtain a diagnosis, mostly due to low cellularity (Skeldon and Dewhurst, 2009). It would follow that in-house examination would reduce the quantity of non-diagnostic slides submitted to referral laboratories. During human renal FNA evaluation, the number of needle passes and microscopic slides examined did not correlate with the adequacy or diagnostic yield of the sample. Instead, sample adequacy correlated with clinician determination of an adequate sample yield using Diff Quik staining (Andonian et al., 2008). (Figures $7 \& 8$ )

\section{Submission to the laboratory}

All slides should be labelled correctly (name of patient, owner and collection site) with pencil, because ink will dissolve during the staining process (Barger, 2014, McGrath, 2008). Formalin-fixed tissues should be placed in a separate bag, because formalin vapour exposure often renders smears non-diagnostic (Raskin and Meyer, 2015, Wypij, 2011). Slides should also be protected by placing in slide mailers and kept separate from fluid submissions in case of leakage within the submission bag.

When sending fluid to the laboratory for testing, containers should be selected based on tests requested. EDTA prevents clot formation and allows accurate cell counting. Under-filling the tube may lead to haemolysis and cell damage, therefore adequate sample should be placed in the tube to reach the 'fill line' (Tri Ratnaningsih, 2006). EDTA can be bacteriostatic or bactericidal and so is unsuitable for culture specimens (Banin et al., 2006). Placing fluid in a plain serum tube allows for biochemistry testing such as bilirubin, creatinine, triglycerides and cholesterol. A plain sterile tube should be used for culture and sensitivity testing. Avoid serum tubes with clot activator or gel because this causes cell disruption and precipitates. 
A direct or line smear of any fluid sent for analysis should accompany the sample, as this will allow cell morphology to be preserved for at least several days, even without fixation (Barger, 2014). (Figure 9)

Immunocytochemistry (ICC) can be performed on cytological samples to determine the lineage of cells through detection of expression of specific cellular protein or antigen (Fisher et al., 1995). This is useful to assist with determination of tumour type, including differentiating between T- and B-cell lymphomas. Several slides containing many intact, well preserved cells are required to perform ICC stains. Polysine-coated slides should be used if ICC may be required, because this special coating helps to ensure cells bind to the slide throughout processing (Huang et al., 1983). Although polysine slides are slightly more expensive than conventional slides, the ability to immunophenotype neoplastic lesions, and thus potentially guide prognosis and treatment from a single sample submission likely justifies the small extra outlay (Huang et al., 1983).

When cytology fails to confirm a diagnosis of lymphoma, more advanced techniques such as flow cytometry or PARR may be required. Flow cytometry uses fluorescent labelled antibodies to evaluate the expression of phenotypic markers, which provides rapid identification and quantification of a large number of cells. Flow cytometry can be performed on FNA specimens and has been shown to be an accurate method for classification of cell lineage for abdominal organ samples in lymphoma patients (Lastra, 2015, Guzera et al., 2016). However, this method requires at least $6 \times 10^{6}$ cells to be mixed with serum or cell preservative and placed in a plain serum tube, and is ideally analysed within 24 hours of collection, although satisfactory results have been achieved in human samples that were several days old (Sigstad et al., 2004, Guzera et al., 2016, University). 
PCR for lymphocyte antigen receptor rearrangement (PARR) is used to evaluate the clonality of a lymphoid population, which can help to differentiate reactive lymphoid tissue from lymphoma. It can be performed on many sample types, including tissue, blood, bone marrow, effusions, cerebrospinal fluid (CSF), and FNA samples (Burnett et al., 2003, Keller et al., 2016). Aspirating a site at least 3 times and expelling the material into physiologic saline and rinsing the syringe each time with saline should give sufficient material for analysis (Burnett et al., 2003). Smear preparations that have already been dried and stained can also be used for PARR, although at least 50,000 cells are required (usually 4 or 5 highly cellular smears) (University, 2016b).

\section{A closer look at sampling specific organs}

\section{Liver}

The successful diagnosis of liver lesions using FNA compares poorly to FNA in other locations (Cohen et al., 2003). Wang et al. (2004) described ultrasound-guided FNA of the liver as having 'serious limitations when used to identify the primary disease process in dogs and cats with clinical evidence of liver disease', with cytologic findings showing agreement with histopathologic results in only $30 \%$ of dogs and $51 \%$ of cats. Cytologic evaluation appears most effective in the diagnosis of fatty change and neoplastic disease and least effective in the diagnosis of inflammatory, dysplastic or hyperplastic conditions (Cohen et al., 2003, Bahr et al., 2013). As would be expected, greater lesion size correlates positively with a successful diagnosis (de Rycke et al., 1999).

Interestingly, in 1 study, liver FNA specimens had high diagnostic sensitivity (82\%) for FIP in cats, which was more impressive than the use of core biopsy (64\% Se) (Giordano et al., 2005). Nevertheless, the cytological findings of pyogranulomatous inflammation are not specific for FIP, and can be seen in many other disease processes. 
Bleeding complications encountered during FNA of the liver have been reported but are rare, even with suboptimal coagulation (Léveillé et al., 1993, Savage et al., 1995, Gazelle et al., 1992). In a retrospective study of 85 human patients with coagulation disorders, ultrasound and laboratory results revealed no bleeding episodes after any of the 229 punctures performed (Caturelli et al., 1993). The complication rate when performing hepatic FNA in animals is not known but FNA is generally estimated to be much safer than liver biopsy, with Bigge et al. (2001) reporting 11 major complications during 254 liver biopsies performed with $18 \mathrm{G}$ needles in dogs and cats with coagulation deficiencies.

\section{Kidney}

Fine needle aspiration of the kidneys is used most commonly as a means of detecting highly cellular neoplasms, such as renal carcinoma or lymphoma but it may also be used to obtain culture material if an infectious agent is suspected. Hypodermic needles of 22 to $25-\mathrm{G}$, with a length of 1.5 to $5 \mathrm{~cm}$ are typically used in animals, whilst for large patients, spinal needles may be used (Osborne et al., 1996).

In humans, ultrasound-guided aspiration of focal renal lesions is considered to be a highly accurate method of diagnosis with minimal organ trauma (Hager et al., 1985). A study by Truong et al. (1999) found that $16 \%$ of renal FNA samples were classified as unsatisfactory when using a 22-25G needle. Of the malignant lesions, cytologic classification of the tumour type was correct in $44 / 46$ cases, whilst $2 / 30$ cases diagnosed on cytologic examination as a benign cyst, were actually cystic renal carcinoma and acquired cystic kidney. Of the 11 cases classified as 'suspicious of malignancy', 4 were later deemed malignant (Truong et al., 1999).

When assessing 22 cats with FIP for the diagnostic sensitivity for detecting FIP in renal lesions, Giordano et al. (2005) found that sensitivity using core biopsy (39\%) was similar to FNA specimens $(42 \%)$. 
Using aspiration during renal FNA has proved better than non-aspiration with respect to diagnostic potential, and there was no statistically significant difference between the results when using 18-, 20-, and 22- gauge needles in healthy pigs (Savage et al., 1995). Complications are less common for renal FNA when compared to renal biopsy (Osborne et al., 1996). That being said, for all needles and at all levels of anticoagulation, greater bleeding resulted from renal biopsy when compared to liver biopsy, likely due to the highly vascular and predominantly arterial nature of the renal blood supply (Gazelle et al., 1992).

A “corresponding” biopsy was defined as a biopsy specimen obtained within 1 day of the cytology specimen. Fifty-six cases were reviewed, including 25 from dogs and 31

from cats. Results were in complete agreement in 34 cases, in partial agreement in 11 cases, and in disagreement

in 11 cases. Agreement occurred most often in cases of fatty change (10 cases) and neoplasia (7 cases of lym-

phoma and 3 cases of epithelial tumor). Disagreement was most common in cases of hepatitis (6 cases) in which inflammation was not seen in cytologic specimens. Other causes for disagreement included fibrosis (2 cases),

and 1 case each of amyloidosis, hemangiosarcoma, and lymphom A “corresponding" biopsy was defined as a biopsy specimen obtained within 1 day of the cytology specimen. Fifty-six cases were reviewed, including 25 from dogs and 31

from cats. Results were in complete agreement in 34 cases, in partial agreement in 11 cases, and in disagreement 
in 11 cases. Agreement occurred most often in cases of fatty change (10 cases) and neoplasia ( 7 cases of lym-

phoma and 3 cases of epithelial tumor). Disagreement was most common in cases of hepatitis (6 cases) in which

inflammation was not seen in cytologic specimens. Other causes for disagreement included fibrosis (2 cases),

and 1 case each of amyloidosis, hemangiosarcoma, and lymphoma.

\section{Spleen}

FNA of the spleen is particularly useful in the diagnosis of infiltrative disorders, such as diffuse neoplasia. However, aspiration of cavitated or fluid-filled lesions such as haematomas or haemangiosarcomas may be inconclusive because of blood dilution (d'Anjou and Penninck, 2015).

Due to the high vascularity of the spleen, there tends to be a pervading fear of complications such as acute haemorrhage or splenic rupture during FNA. However, splenic aspiration is performed frequently at our institution, accounting for approximately $25 \%$ of all abdominal organ FNA submissions in 2016 (unpublished data). Major complications are rare in human literature, with large scale studies indicating a major complication rate of $<1 \%$ (Gochhait et al., 2015, Cavanna et al., 2007, Silverman et al., 1993, Keogan et al., 1999, Civardi et al., 2001b). Large-scale veterinary studies are scarce, but there are many published case series with no serious complications encountered during splenic FNA (Watson et al., 2011, Léveillé et al., 1993), even in 14 thrombocytopenic animals (O'Keefe and Couto, 1987). However, thrombocytopenia does appear to contribute to complication rate during core biopsy of the spleen using $18 \mathrm{G}$ needles (Bigge et al., 2001). 
Human studies have demonstrated a definitive diagnosis could be confirmed in 88/130 (68\%) of cases using splenic FNA, with results improving with greater operator experience (Civardi et al., 2001b, Gochhait et al., 2015).

In a small study by O'Keefe and Couto (1987), 14 dogs and cats underwent both splenic FNA and histologic evaluation of splenic lesions; all cytologic diagnoses correlated well with their final histologic diagnoses. However, other studies show a poorer level of accuracy when performing splenic FNA. In 32 dogs and cats with splenic lesions, there was a diagnostic correlation of $61 \%$ between cytological and histological interpretation (Ballegeer et al., 2007). In another study of diagnostic samples from 35 dogs, cytopathologic and histopathologic diagnoses agreed completely in $18 / 35$ dogs (51\%), partially in $3 / 35$ dogs (9\%), and were in disagreement in 14/35 dogs (40\%) (Watson et al., 2011). Non-aspiration techniques appear superior during FNA of the spleen in both cats and dogs, because they produce samples of greater cellularity and less blood contamination (LeBlanc et al., 2009).

\section{Pancreas}

In humans, endoscopic ultrasound-guided FNA of the pancreas is frequently utilised, especially in the diagnosis of pancreatic neoplasia and, although this method has been described in animals, ultrasound-guided FNA is a more common technique (Lewitowicz et al., 2012, Zamboni et al., 2009, Kook et al., 2012, Gaschen et al., 2007, Gaschen et al., 2003). In Bonfanti's report of 102 FNA samples submitted from abdominal masses, only 1 was from the pancreas (Bonfanti et al., 2004). At our institution, 17 pancreatic FNA samples were submitted in 2016, of which 5 were considered non-diagnostic (unpublished data).

In a large-scale human study, ultrasound-guided pancreatic FNA samples were diagnostic in 509/545 cases (93.4\%), although it should be noted that these procedures benefited from an on-site cytopathologist, which allowed immediate assessment of sample adequacy (Zamboni 
et al., 2009). If the 36 non-diagnostic samples were excluded, the procedure achieved $99.4 \%$ sensitivity, $100 \%$ specificity, and $99.4 \%$ accuracy, with no major complications observed.

In a large-scale veterinary study, pancreatic FNA samples obtained via both non-aspiration and aspiration methods from 94 dogs undergoing pancreatic FNA for clinical diagnostic evaluation were reviewed. Twenty-five samples (27\%) were non-diagnostic, predominantly because of low cellularity. Cytologic and histologic findings agreed in 10/11 cases (91\%). Clinical complications following pancreatic FNA in this case series were considered uncommon (6.3\%). The majority of dogs with complications had concurrent diagnostic procedures performed and significant co-morbidities and, in most cases, pancreatic FNA was considered unlikely to be the primary cause of the complications (Cordner et al., 2015). Interestingly, in another study by Cordner et al., 20 healthy dogs had ultrasound-guided pancreatic FNA performed, which revealed that none of the 20 samples had sufficient cellularity to be considered of diagnostic quality. Ultrasound-guided FNA fared much worse than intraoperative aspirates (67\% of diagnostic quality) and touch impressions from biopsy samples (78\% of diagnostic quality). The authors of this study suggested 2 possible reasons for these findings: the poorly cellular samples obtained via US-guided FNA of normal pancreatic tissue may be poorly exfoliative due to a tightly associated fibrovascular network when compared to diseased organs, as well as limited operator experience during FNA sampling. A more encouraging finding of this study concluded that ultrasound-guided FNA did not lead to significant increases in serum concentrations of pancreatic enzymes, suggesting minimal trauma to the pancreas (Cordner et al., 2010).

In a study involving 73 cats with pancreatic disease, 24/73 (67\%) of cytologic samples obtained via both aspiration and non-aspiration ultrasound-guided FNA of the pancreas were diagnostic. No cats developed complications within 48 hours of the pancreatic FNA procedure, and there was no difference in complication incidence or survival to discharge 
when compared to cats with pancreatic disease that did not undergo pancreatic FNA. Pancreatic cytology and histopathology were in agreement in 7/9 cases (Crain et al., 2015).

\section{Bladder}

Urothelial cell carcinoma is easily the most common bladder tumour in both dogs and cats (Osborne et al., 1968, Norris et al., 1992, Meuten, 2016, Mutsaers et al., 2003), and is 1 of the most malignant tumours in domestic animals, with only $16 \%$ of treated dogs surviving for 1 year or more, and metastases present in $50-90 \%$ of dogs and $50 \%$ of cats at necropsy (Norris et al., 1992, Meuten, 2016).

Options for collection of cytologic samples from bladder masses include urine cytology, traumatic catheterisation, cystoscopy, and ultrasound guided FNA. The quality of samples obtained via urine cytology or traumatic catheterisation varies (Fulkerson and Knapp, 2015), and urine samples are reported to be poorly sensitive for the diagnosis of neoplasia, with malignant cells detected in only 29/96 (30\%) of urinary sediments in dogs with bladder tumours (Raskin and Meyer, 2015, Norris et al., 1992).

Bladder FNA is considered a relatively reliable method of diagnosing bladder tumours in both cats and dogs. (Wilson et al., 2007, Walker et al., 1993, Wypij, 2011). Bladder tumours were successfully diagnosed by FNA in 20/22 (91\%) dogs and in 10/13 (77\%) dogs using urethral wash methods (Norris et al., 1992). In a study by Bonfanti et al. (2004), 8/9 canine and feline urinary bladder FNAs correlated well with histopathologic diagnoses, and included various types of bladder neoplasms and inflammatory conditions, with $1 / 9$ cases proving to be non-diagnostic.

Despite the reliability of FNA in the diagnosis of bladder masses, there is some hesitance to perform the procedure because of the perceived risks of tumour seeding. Abdominal wall metastasis following FNA and core biopsy, and surgical implantation associated with 
cystotomy and laparotomy has been reported in dogs, although some of these cases had concurrent evidence of other metastatic disease such as involvement of lungs and lymph nodes at diagnosis, in accordance with the highly aggressive nature of these tumours (Nyland et al., 2002, Higuchi et al., 2013). In a study of 544 UCC cases at 1 institution, 24 cases of abdominal wall metastasis were identified (4.4\% of UCC cases) including 18 associated with cystotomy or laparotomy (3.3\%), 2 associated with FNA of the bladder or prostate $(0.36 \%)$, and 4 cases with no evident inciting cause, including 1 case with evidence of transmural spread of the tumour $(0.72 \%)$ (Higuchi et al., 2013). In another report of 12 dogs with cutaneous metastasis of UCC without abdominal muscle involvement, all dogs had evidence of other sites of metastasis at diagnosis, most had evidence of lymphatic invasion suggesting lymphatic spread was a potential mechanism for the cutaneous metastases and, interestingly, 11 of these cases had metastases in close proximity to the vulva. The authors proposed implantation of neoplastic cells from urine into erosions of urine scalded skin as another potential mechanism for metastasis (Reed et al., 2013). In our opinion, the uncommon-to-rare risk of needle tract metastasis associated with this tumour is outweighed by the ability to make a rapid, minimally-invasive cytologic diagnosis through FNA cytology, although the risk should be discussed with the owner, as once UCC becomes established in the abdominal wall and clinically detectable at that site, it appears that medical treatment is rarely effective (Higuchi et al., 2013).

\section{Prostate}

Disorders of the prostate gland occur commonly in older dogs. Although various methods of obtaining prostatic samples have been described, including prostatic wash, semen evaluation and urine sediment examination (Barsanti and Finco, 1984, Raskin and Meyer, 2015), preparations obtained by these methods typically includes contaminants from the reproductive and urinary tract and so direct FNA is considered a superior method of 
collection (Cowell and Tyler, 2002, Thrall, 1985). Indeed, at our institution, all prostatic cytologic samples submitted to the laboratory in $2016(\mathrm{n}=17)$ were obtained via ultrasoundguided FNA (unpublished data).

Apart from the possible complications associated with needle tract seeding, other reported contraindications include the potential for contamination of the abdominal cavity leading to septic peritonitis or bacteraemia following FNA of prostatic abscesses (Raskin and Meyer, 2015, Thrall, 1985). However, drainage of prostatic abscesses has been described in 53 dogs without any post-operative complications, and can provide a minimally-invasive method of diagnosis and an important adjunct to treatment (Boland et al., 2003, Bussadori et al., 1999).

Of 25 cytological samples collected by various methods from the canine prostate, including 16 by ultrasound-guided FNA, the primary diagnoses consisted of the following: benign prostatic hyperplasia $(\mathrm{BPH})(\mathrm{n}=8)$, neoplasia $(\mathrm{n}=8)$, inflammation $(\mathrm{n}=4)$, non-diagnostic $(\mathrm{n}$ $=2)$, squamous metaplasia $(n=2)$, and prostatic cyst $(n=1)$ (Powe et al., 2004). Another study found similar proportions of diagnoses during cytological examination of canine prostatic disease (Thrall, 1985).

Ultrasound-guided prostatic FNA samples were concordant with the final diagnosis in 12/16 cases in 1 study (Powe et al., 2004), 11/12 samples in another (Thrall, 1985) and showed a sensitivity of $77 \%$ and specificity of $100 \%$ for the diagnosis of $\mathrm{BPH}$, and $100 \%$ sensitivity/specificity for the diagnosis of chronic prostatitis in a study of 16 dogs (González, 2010). Interestingly, in the study by Powe et al. (2004), there was good agreement between prostatic massage/wash samples and histologic diagnosis, with 8/9 samples showing concordance, however in the study by Thrall (1985), FNA $(n=15)$ was found to produce greater yields and more reliable results than prostatic wash $(n=11)$. 
Cytology was found to be a more sensitive method for the diagnosis of septic prostatitis $(n=5)$ than biopsy (Powe et al., 2004).

\section{Abdominal lymph nodes}

The results of US-guided FNA from various lymph nodes in 179 human patients obtained samples that were sufficient for cytological analysis in $97 \%$ of cases. Correct benign and malignant cytological diagnoses were achieved in 97\% (33/34) of deep abdominal and retroperitoneal lesions (Tikkakoski et al., 1991).

Many studies have demonstrated increased diagnostic capabilities using a non-aspiration technique in lymph nodes, because suction often produces a haemodiluted sample. In 34 human patients, an average of 2.4 needle passes (range 1-5) were used for abdominal and pelvic lymph nodes with a correct specific diagnosis made in $86 \%$ of cases (Fisher et al., 1997).

In a study of 1274 canine lymph nodes aspirates from various locations, the median number of slides submitted per patient following lymph node aspiration was 3 , and in dogs, the number of slides was significantly associated with an increased probability of obtaining both a diagnostic specimen and a cytological diagnosis (Amores-Fuster et al., 2015). In feline samples the association was not significant, although this may be due to a smaller sample size (Amores-Fuster et al., 2015). Of the canine samples, 73\% were diagnostic, whilst of the 199 feline lymph nodes aspirates evaluated, $86 \%$ were considered diagnostic. The most common reasons for a non-diagnostic sample included the absence of nucleated cells, cell disruption and a low yield (Amores-Fuster et al., 2015). It is important to note that the lymph node samples in this study were not specifically from the abdomen, and in our experience, obtaining samples from abdominal lymph nodes is more likely to be non-diagnostic compared with subcutaneous lymph nodes. Review of lymph node submissions to our 
institution in 2016 found $30 \%$ of 64 abdominal lymph node samples were non-diagnostic, compared with $23 \%$ of 138 lymph node samples submitted from other anatomic locations (unpublished data). It is therefore recommended to obtain a minimum of 3 non-aspiration FNAs for each abdominal lymph node sampled, and ideally more. We also recommend extra care when extruding aspirated material onto slides and when making smears to avoid rupture of the cells, because lymphocytes are fragile, particularly neoplastic lymphocytes.

The most common diagnosis from canine lymph node FNA is lymphoma $(27.5 \%)$ (SapierzyDski and MicuD, 2009, Amores-Fuster et al., 2015), whilst in cats reactive hyperplasia is most commonly diagnosed (32\%) (Amores-Fuster et al., 2015).

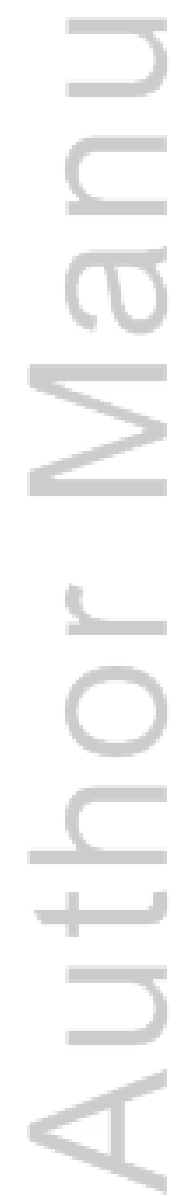

This article is protected by copyright. All rights reserved. 


\section{Conclusion}

Ultrasound-guided FNA of abdominal organs can provide a minimally-invasive assessment of underlying disease, with a low complication rate. Although a final diagnosis may not be possible for all lesions by cytology alone, it can be used as a tool to help narrow the differential diagnosis list, thus guiding treatment and prognosis and is therefore an invaluable diagnostic tool for veterinary clinicians. The use of optimal techniques to obtain the highest quality FNA samples will increase the chance of obtaining a diagnostic quality sample.

No conflicts of interest have been declared.

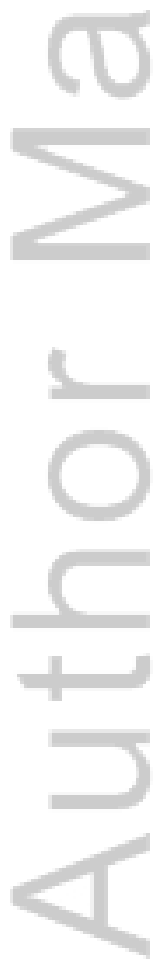

This article is protected by copyright. All rights reserved. 


\section{References}

Veterinary Laboratory Medicine: Small and Exotic Animals. Clinics in Laboratory Medicine, 35 , i.

ABELE, J. S., MILLER, T. R., KING, E. B. \& LOWHAGEN, T. 1985. Smearing techniques for the concentration of particles from fine needle aspiration biopsy. Diagnostic Cytopathology, 1, 59-65.

AMORES-FUSTER, I., CRIPPS, P., GRAHAM, P., MARRINGTON, A. M. \& BLACKWOOD, L. 2015. The diagnostic utility of lymph node cytology samples in dogs and cats. Journal of Small Animal Practice, 56, 125-129.

ANDONIAN, S., OKEKE, Z., OKEKE, D. A., SUGRUE, C., WASSERMAN, P. G. \& LEE, B. R. 2008. Number of needle passes does not correlate with the diagnostic yield of renal fine needle aspiration cytology. Journal of endourology / Endourological Society, 22, 2377-2380.

BABB, R. R. \& JACKMAN, R. J. 1989. Needle biopsy of the liver. A critique of four currently available methods. The Western journal of medicine, 150, 39-42.

BAHR, K. L., SHARKEY, L. C. \& MURAKAMI, T. 2013. Accuracy of US-guided FNA of focal liver lesions in dogs: 140 cases (2005-2008). Journal of the ....

BAIG, M., FATHALLAH, L., FENG, J., HUSAIN, M., GRIGNON, D. \& AL-ABBADI, M. 2006. Fast drying of Fine Needle Aspiration slides using a hand held fan : Impact on turn around time and staining quality. CytoJournal, 3, 12-12.

BALLEGEER, E. A., FORREST, L. J., DICKINSON, R. M., SCHUTTEN, M. M., DELANEY, F. A. \& YOUNG, K. M. 2007. Correlation of ultrasonographic appearance of lesions and cytologic and histologic diagnoses in splenic aspirates from dogs and cats: 32 cases (2002-2005). Journal of the American Veterinary Medical Association, 230, 690-696.

This article is protected by copyright. All rights reserved. 
BANIN, E., BRADY, K. M. \& GREENBERG, E. P. 2006. Chelator-induced dispersal and killing of Pseudomonas aeruginosa cells in a biofilm. Applied and environmental ....

BARGER, A. M. 2014. Diagnostic Cytology and Hematology of the Dog and Cat, 4th edition by Editors: Rick L. Cowell, Ronald D. Tyler, James H. Meinkoth, Dennis B. DeNicola. Veterinary Clinical Pathology, 37.

BARSANTI, J. A. \& FINCO, D. R. 1984. Evaluation of techniques for diagnosis of canine prostatic diseases. Journal of the American Veterinary Medical Association, 185, 198200.

BIGGE, L. A., BROWN, D. J. \& PENNINCK, D. G. 2001. Correlation between coagulation profile findings and bleeding complications after ultrasound-guided biopsies: 434 cases (1993-1996). Journal of the American Animal Hospital Association, 37, 228233.

BINEK, J., SPIELER, P., HÜRLIMANN, R., ZOEBELI, L. \& HAMMER, B. 1995. Ultrasound-guided fine-needle aspiration of abdominal masses: Accuracy and shortterm complications. European Journal of Ultrasound, 2, 199-203.

BOLAND, L., HARDIE, R., GREGORY, S. \& LAMB, C. 2003. Ultrasound-guided percutaneous drainage as the primary treatment for prostatic abscesses and cysts in dogs. Journal of the American Animal Hospital Association, 39, 151-159.

BONFANTI, U., BUSSADORI, C., ZATELLI, A., LORENZI, D., MASSERDOTTI, C., BERTAZZOLO, W., FAVERZANI, S., GHISLENI, G., CAPOBIANCO, R. \& CANIATTI, M. 2004. Percutaneous fine-needle biopsy of deep thoracic and abdominal masses in dogs and cats. Journal of Small Animal Practice, 45, 191-198.

BRENNAN, P. A., MACKENZIE, N., OEPPEN, R. S., KULAMARVA, G., THOMAS, G. J. \& SPEDDING, A. V. 2007. Prospective randomized clinical trial of the effect of 
needle size on pain, sample adequacy and accuracy in head and neck fine-needle aspiration cytology. Head \& Neck, 29, 919-922.

BURNetT, R. C., VERnAU, W., MODiAnO, J. F., OLVER, C. S., MOORE, P. F. \& AVERY, A. C. 2003. Diagnosis of Canine Lymphoid Neoplasia Using Clonal Rearrangements of Antigen Receptor Genes. Veterinary Pathology Online, 40, 32-41. BUSSADORI, C., BIGLIARDI, E., D'AGNOLO, G., BORGARELLI, M. \& SANTILLI, R. A. 1999. [The percutaneous drainage of prostatic abscesses in the dog]. Radiol Med, 98, 391-4.

CATURElli, E., SQUillante, M., ANDRIUlli, A., SIENA, D., CELlERINO, C., LUCA, F., MARZANO, M., POMPILI, M. \& RAPACCLNI, G. 1993. Fine-needle liver biopsy in patients with severely impaired coagulation. Liver, 13, 270-273.

CAVANNA, L., LAZZARO, A., VALLISA, D., CIVARDI, G. \& ARTIOLI, F. 2007. Role of image-guided fine-needle aspiration biopsy in the management of patients with splenic metastasis. World Journal of Surgical Oncology, 5, 1-6.

CIVARDI, G., VALliSA, D., BERTÈ, R., GIORGIO, A., FILICE, C., CAREMANI, M., CATURELLI, E., POMPILI, M., SIO, I., BUSCARINI, E. \& CAVANNA, L. 2001a. Ultrasound-guided fine needle biopsy of the spleen: High clinical efficacy and low risk in a multicenter Italian study. American Journal of Hematology, 67, 93-99.

CIVARDI, G., VAlliSA, D., BERTÈ, R., GIORGIO, A., FILICE, C., CAREMANI, M., CATURElli, E., POMPILI, M., SIO, I. D., BUSCARINI, E. \& CAVANNA, L. 2001b. Ultrasound-guided fine needle biopsy of the spleen: High clinical efficacy and low risk in a multicenter Italian study. American Journal of Hematology, 67, 93-99.

COHEN, M., BOHLING, M. W. \& WRIGHT, J. C. 2003. Evaluation of sensitivity and specificity of cytologic examination: 269 cases (1999-2000). Journal of the ....

This article is protected by copyright. All rights reserved. 
CORDNER, A. P., ARMSTRONG, P. J., NEWMAN, S. J., NOVO, R., SHARKEY, L. C. \& JESSEN EMERITUS, C. 2010. Effect of pancreatic tissue sampling on serum pancreatic enzyme levels in clinically healthy dogs. Journal of veterinary diagnostic investigation : official publication of the American Association of Veterinary Laboratory Diagnosticians, Inc, 22, 702-707.

CORDNER, A. P., SHARKEY, L. C., ARMStRong, J. P. \& MCATEER, K. D. 2015. Cytologic findings and diagnostic yield in 92 dogs undergoing fine-needle aspiration of the pancreas. Journal of Veterinary Diagnostic Investigation, 27, 236-240.

COWELL, R. L. \& TYLER, R. D. 2002. Diagnostic Cytology and Hematology of the Horse, Mosby.

CRAIN, S. K., SHARKEY, L. C., CORDNER, A. P., KNUDSON, C. \& ARMSTRONG, J. P. 2015. Safety of ultrasound-guided fine-needle aspiration of the feline pancreas: a case-control study. Journal of Feline Medicine and Surgery, 17, 858-863.

D'ANJOU, M.-A. \& PENNINCK, D. 2015. Atlas of Small Animal Ultrasonography, Ames, Iowa, Wiley-Blackwell.

DÄHNERT, W. F., HOAGLAND, M. H., HAMPER, U. M., EROZAN, Y. S. \& PEIRCE, J. C. 1992. Fine-needle aspiration biopsy of abdominal lesions: diagnostic yield for different needle tip configurations. Radiology, 185, 263-268.

DALTREY, I. R. \& KISSIN, M. W. 2000. Randomized clinical trial of the effect of needle gauge and local anaesthetic on the pain of breast fine-needle aspiration cytology. British Journal of Surgery, 87, 777-779.

DE RYCKE, L., VAN BREE, H. \& SIMOENS, P. 1999. ULTRASOUND-GUIDED TISSUE-CORE BIOPSY OF LIVER, SPLEEN AND KIDNEY IN NORMAL DOGS. Veterinary Radiology \& Ultrasound, 40, 294-299. 
FISHER, A. J., PAULSON, E. K., SHEAFOR, D. H., SIMMONS, C. M. \& NELSON, R. C. 1997. Small lymph nodes of the abdomen, pelvis, and retroperitoneum: usefulness of sonographically guided biopsy. Radiology, 205, 185-190.

FISHER, D. J., NAYDAN, D., WERNER, L. L. \& MOORE, P. F. 1995. Immunophenotyping Lymphomas in Dogs: A Comparison of Results From Fine Needle Aspirate and Needle Biopsy Samples. Veterinary Clinical Pathology, 24, 118 123.

FULKERSON, C. M. \& KNAPP, D. W. 2015. Management of transitional cell carcinoma of the urinary bladder in dogs: A review. The Veterinary Journal, 205, 217-225.

GANI, S. M., SHAFEE, A. M. \& SOLIMAN, I. Y. 2011. Ultrasound guided percutaneous fine needle aspiration biopsy / automated needle core biopsy of abdominal lesions: Effect on management and cost effectiveness. Annals of African Medicine, 10, 133.

GASCHEN, L., KIRCHER, P. \& LANG, J. 2003. ENDOSCOPIC ULTRASOUND INSTRUMENTATION, APPLICATIONS IN HUMANS, AND POTENTIAL VETERINARY APPLICATIONS. Veterinary Radiology \& Ultrasound, 44, 665-680. GASCHEN, L., KIRCHER, P. \& WOLFRAM, K. 2007. ENDOSCOPIC ULTRASOUND OF THE CANINE ABDOMEN. Veterinary Radiology \& Ultrasound, 48, 338-349.

GAZELLE, G. S., HAAGA, J. R. \& ROWLAND, D. Y. 1992. Effect of needle gauge, level of anticoagulation, and target organ on bleeding associated with aspiration biopsy. Work in progress. Radiology, 183, 509-513.

GIORDANO, A., PALTRINIERI, S., BERTAZZOLO, W., MILESI, E. \& PARODI, M. 2005. Sensitivity of Tru-cut and fine-needle aspiration biopsies of liver and kidney for diagnosis of feline infectious peritonitis. Veterinary Clinical Pathology, 34, 368-374.

This article is protected by copyright. All rights reserved. 
GOCHHAIT, D., DEY, P., RAJWANSHI, A., NIJHAWAN, R., GUPTA, N., RADHIKA, S. \& LAL, A. 2015. Role of Fine needle aspiration cytology of spleen. APMIS, 123, 190193.

GONZÁLEZ, G. 2010. Sensibilidad y especificidad de la aspiración biopsia con aguja fina guiada por ecografía para el diagnóstico de hiperplasia prostática y prostatitis crónica canina. Revista cientifica, 20, 617-622.

GRANT, E. G., RICHARDSON, J. D., SMIRNIOTOPOULOS, J. G. \& JACOBS, N. M. 1983. Fine-needle biopsy directed by real-time sonography: technique and accuracy. American Journal of Roentgenology, 141, 29-32.

GUZERA, M., CIAN, F., LEO, C., WINNICKA, A. \& ARCHER, J. 2016. The use of flow cytometry for immunophenotyping lymphoproliferative disorders in cats: a retrospective study of 19 cases. Veterinary and Comparative Oncology, 14, 40-51.

HAGER, D. A., NYLAND, T. G. \& FISHER, P. 1985. ULTRASOUND-GUIDED BIOPSY OF THE CANINE LIVER, KIDNEY, AND PROSTATE. Veterinary Radiology, 26, $82-88$

HASELER, L. J., SIBBITT, R. R., SIBBITT, W. L., MICHAEL, A. A., GASPAROVIC, C. M. \& BANKHURST, A. D. 2011. Syringe and Needle Size, Syringe Type, Vacuum Generation, and Needle Control in Aspiration Procedures. CardioVascular and Interventional Radiology, 34, 590-600.

HIGUCHI, T., BURCHAM, G., CHILDRESS, M., ROHLEDER, J., BONNEY, P., RAMOS VARA, J. \& KNAPP, D. 2013. Characterization and treatment of transitional cell carcinoma of the abdominal wall in dogs: 24 cases (1985-2010). Journal of the American Veterinary Medical Association, 242, 499-506.

This article is protected by copyright. All rights reserved. 
HUANG, W. M., GIBSON, S. J., FACER, P., GU, J. \& POLAK, J. M. 1983. Improved section adhesion for immunocytochemistry using high molecular weight polymers of 1-lysine as a slide coating. Histochemistry, 77, 275-279.

JACKSON, D. E., SELTING, K. A., SPOOR, M. S., HENRY, C. J. \& WIEDMEYER, C. E. 2013. Evaluation of fixation time using Diff-Quik for staining of canine mast cell tumor aspirates. Veterinary Clinical Pathology, 42, 99-102.

JAHROMI, A., BALLARD, D., BAHRAMI, R. \& D'AGOSTINO, H. 2015. Comparison of Different Techniques of Ultrasound-Guided Fine Needle Biopsy of Liver in a Swine Model. Hepatitis Monthly, 15.

JÖRUNDSSON, E., LUMSDEN, J. H. \& JACOBS, R. M. 1999. Rapid Staining Techniques in Cytopathology: A Review and Comparison of Modified Protocols for Hematoxylin and Eosin, Papanicolaou and Romanowsky Stains. Veterinary Clinical Pathology, 28, 100-108.

KELLER, S. M., VERNAU, W. \& MOORE, P. F. 2016. Clonality Testing in Veterinary Medicine: A Review With Diagnostic Guidelines. Veterinary pathology, 53, 711-725.

KEOGAN, M. T., FREED, K. S., PAULSON, E. K., NELSON, R. C. \& DODD, L. G. 1999. Imaging-guided percutaneous biopsy of focal splenic lesions: update on safety and effectiveness. AJR. American journal of roentgenology, 172, 933-937.

KINNEY, T. B., LEE, M. J., FILOMENA, C. A. \& KREBS, T. L. 1993. Fine-needle biopsy: prospective comparison of aspiration versus nonaspiration techniques in the abdomen. Radiology.

KOOK, P. H., BALOI, P., RUETTEN, M., PANTCHEV, N., REUSCH, C. E. \& KIRCHER, P. 2012. Feasibility and Safety of Endoscopic Ultrasound-Guided Fine Needle Aspiration of the Pancreas in Dogs. Journal of Veterinary Internal Medicine, 26, 513517.

This article is protected by copyright. All rights reserved. 
LASTRA, R. R., PRAMICK R. M, BALOCH, Z.W 2015. Fine-needle Aspiration Biopsy Techniques. In: WILBUR, M. B. A. D. (ed.) Comprehensive cytopathology. 4th ed.: Saunders.

LEBLANC, C. J., HEAD, L. L. \& FRY, M. M. 2009. Comparison of aspiration and nonaspiration techniques for obtaining cytologic samples from the canine and feline spleen. Veterinary Clinical Pathology, 38, 242-246.

LÉVEIllÉ, R., PARTINGTON, B. P., BILleR, D. S. \& MiYABAYASHI, T. 1993. Complications after ultrasound-guided biopsy of abdominal structures in dogs and cats: 246 cases (1984-1991). Journal of the American Veterinary Medical Association, 203, 413-415.

LEWITOWICZ, P., MATYKIEWICZ, J., HECIAK, J., KOZIEL, D. \& GLUSZEK, S. 2012. Percutaneous Fine Needle Biopsy in Pancreatic Tumors: A Study of 42 Cases. Gastroenterology Research and Practice, 2012, 908963.

LIVET, V., SONET, J., SAADEH, D., PILlARD, P. \& CAROZZO, C. 2016. Needle-tract implantation after fine-needle aspiration biopsy of a renal cell carcinoma in a dog. Veterinary Record Case Reports, 4, e000349.

LIVRAGHI, T., DAMASCELLI, B., LOMBARDI, C. \& SPAGNOLI, I. 1983. Risk in fineneedle abdominal biopsy. Journal of Clinical Ultrasound, 11, 77-81.

MCGRATH, C., YU, G, ET AL. 2008. Fine Needle Aspiration [Online]. Glob. libr. women's med. Available: https://www.glowm.com/section_view/heading/Fine\%20Needle\%20Aspiration/item/2 $\underline{63}$ [Accessed 15th August 2016].

MENARD, M. \& PAPAGEORGES, M. 1995. ULTRASOUND CORNER TECHNIQUE FOR ULTRASOUND-GUIDED FINE NEEDLE BIOPSIES. Veterinary Radiology \& Ultrasound, 36, 137-138.

This article is protected by copyright. All rights reserved. 
MENARD, M. \& PAPAGEORGES, M. 1996. Ultrasound-guided liver fine needle biopsies in dogs; Results of 600 cases. Veterinary Pathology, 33, 570.

MEUTEN, D. J. 2008. Tumors in Domestic Animals, Wiley.

MEUTEN, D. J. 2016. Tumors in Domestic Animals, Wiley.

MUTSAERS, A. J., WIDMER, W. R. \& KNAPP, D. W. 2003. Canine Transitional Cell Carcinoma. Journal of Veterinary Internal Medicine, 17, 136-144.

NORRIS, A. M., LAING, E. J., VALLI, V. E. O., WITHROW, S. J., MACY, D. W., OGILVIE, G. K., TOMLINSON, J., MCCAW, D., PIDGEON, G. \& JACOBS, R. M. 1992. Canine Bladder and Urethral Tumors: A Retrospective Study of 115 Cases (1980-1985). Journal of Veterinary Internal Medicine, 6, 145-153.

NYLAND, T. G., WALLACK, S. T. \& WISNER, E. R. 2002. NEEDLE-TRACT IMPLANTATION FOLLOWING US-GUIDED FINE-NEEDLE ASPIRATION BIOPSY OF TRANSITIONAL CELL CARCINOMA OF THE BLADDER, URETHRA, AND PROSTATE. Veterinary Radiology \& Ultrasound, 43, 50-53.

O'KEEFE, D. A. \& COUTO, G. C. 1987. Fine-Needle Aspiration of the Spleen as an Aid in the Diagnosis of Splenomegaly. Journal of Veterinary Internal Medicine, 1, 102-109.

OSBORNE, C. A., BARTGES, J. W., POLZIN, D. J., LULICH, J. P., JOHNSTON, G. R. \& COX, V. 1996. Percutaneous Needle Biopsy of the Kidney Indications, Applications, Technique, and Complications. Veterinary Clinics of North America: Small Animal Practice, 26, 1461-1504.

OSBORNE, C. A., LOW, D. G., PERMAN, V. \& BARNES, D. M. 1968. Neoplasms of the canine and feline urinary bladder: incidence, etiologic factors, occurrence and pathologic features. Am J Vet Res, 29, 2041-55.

PAGANI, J. J. 1983. Biopsy of focal hepatic lesions. Comparison of 18 and 22 gauge needles. Radiology, 147, 673-675.

This article is protected by copyright. All rights reserved. 
PAPAGEORGES, M. M. A. M. 1996. ULTRASOUND-GUIDED LIVER FINE NEEDLE BIOPSIES IN CATS: RESULTS OF 307 CASES. Veterinary Pathology, 33, 570.

POWE, J. R., CANFIELD, P. J. \& MARTIN, P. A. 2004. Evaluation of the cytologic diagnosis of canine prostatic disorders. Veterinary Clinical Pathology, 33, 150-154.

PUJANI, M., JETLEY, S., JAIRAJPURI, Z. S., KHAN, S., HASSAN, M. J., RANA, S. \& KUMAR, M. 2016. A Critical Appraisal of the Spectrum of Image Guided Fine Needle Aspiration Cytology: A Three Year Experience from a Tertiary Care Centre in Delhi. Turk patoloji dergisi, 32, 27-34.

RASKIN, R. E. 1000. GENERAL PRINCIPLES OF CYTOLOGIC INTERPRETATION. Proceeding of the NAVC North American Veterinary Conference.

RASKIN, R. E. \& MEYER, D. 2015. Canine and Feline Cytology: A Color Atlas and Interpretation Guide, Elsevier Health Sciences.

REED, L. T., KNAPP, D. W. \& MILLER, M. A. 2013. Cutaneous Metastasis of Transitional Cell Carcinoma in 12 Dogs. Veterinary Pathology, 50, 676-681.

SAJEEV, S. \& SIDDARAJU, N. 2009. A comparative analysis of fine-needle capillary cytology vs. fine-needle aspiration cytology in superficial lymph node lesions. Diagnostic Cytopathology, 37, 787-791.

SAPIERZYCSKI, R. \& MICUC, J. 2009. Lymphadenomegaly in dogs--cytological study. Polish Journal of Veterinary Sciences, 12, 263-268.

SAVAGE, C. A., HOPPER, K. D., ABENDROTH, C. S. \& HARTZEL, J. S. 1995. Fineneedle aspiration biopsy versus fine-needle capillary (nonaspiration) biopsy: in vivo comparison. Radiology.

SIGSTAD, E., DONG, H. P. \& DAVIDSON, B. 2004. The role of flow cytometric immunophenotyping in improving the diagnostic accuracy in referred fine-needle aspiration specimens. Diagnostic ....

This article is protected by copyright. All rights reserved. 
SILVERMAN, J. F. \& FRABLE, W. J. 1990. The use of the diff-quik stain in the immediate interpretation of fine-needle aspiration biopsies. Diagnostic Cytopathology, 6, 366369.

SILVERMAN, J. F., GEISINGER, K. R., RAAB, S. S. \& STANLEY, M. W. 1993. Fine needle aspiration biopsy of the spleen in the evaluation of neoplastic disorders. Acta cytologica, 37, 158-162.

SIROIS, M. 2012. Elsevier's Veterinary Assisting Textbook1: Elsevier's Veterinary Assisting Textbook, Elsevier/Mosby.

SKELDON, N. \& DEWHURST, E. 2009. The perceived and actual diagnostic utility of veterinary cytological samples. Journal of Small Animal Practice, 50, 180-185.

SMITH, E. H. 1991. Complications of percutaneous abdominal fine-needle biopsy. Review. Radiology, 178, 253-258.

THRALL, M. A. 1985. Cytologic diagnosis of canine prostatic disease. Journal of the American Animal Hospital Association, 21, 95-102.

TIKKAKOSKI, T., SINILUOTO, T., OLLIKAINEN, A., PÄIVÁNSALO, M., LOHELA, P. \& APAJA-SARKKINEN, M. 1991. Ultrasound-Guided Aspiration Cytology of Enlarged Lymph Nodes. Acta Radiologica, 32, 53-56.

TITORIA, P., SIVA, T. M. \& MALIK, T. 2010. An assessment of fine-needle sampling techniques. Annals of The Royal College of Surgeons of England, 92, 429.

TRI RATNANINGSIH, U. S., RIZKI A. GUMILANG 2006. The effects of excessive disodium ethylene diamine tetraacetic acid (Na2EDTA) anticoagulant concentration toward hematology profile and morphology of erythrocytes in peripheral blood examination. Medical Journal of Indonesia, 15, 157-164.

This article is protected by copyright. All rights reserved. 
TRUONG, L. D., TODD, T. D., DHURHAR, B. \& RAMZY, I. 1999. Fine-needle aspiration of renal masses in adults: Analysis of results and diagnostic problems in 108 cases. Diagnostic Cytopathology, 20, 339-349.

UNIVERSITY, C. S. 2016a. Flow Cytometry Submission Instructions [Online]. College of Veterinary Medicine and Surgery- Colarado State University: Department of Microbiology, Immunology and Pathology. Available: http://csucvmbs.colostate.edu/academics/mip/ci-lab/Pages/Flow-Cytometry-Instructions.aspx [Accessed 2016].

UNIVERSITY, C. S. 2016b. PARR Testing Submission Instructions [Online]. Colorado State University. Available: $\quad$ http://csu-cvmbs.colostate.edu/academics/mip/ci-

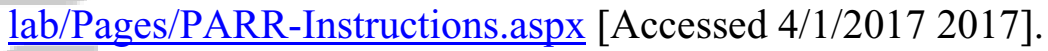

VADEN, S. L., LEVINE, J. F., LEES, G. E., GROMAN, R. P., GRAUER, G. F. \& FORRESTER, D. S. 2005. Renal Biopsy: A Retrospective Study of Methods and Complications in 283 Dogs and 65 Cats. Journal of Veterinary Internal Medicine, 19, 794-801.

VIGNOLI, ROSSI, CHIERICI, TERRAGNI, LORENZI, D., STANGA \& OLIVERO 2007. Needle tract implantation after fine needle aspiration biopsy (FNAB) of transitional cell carcinoma of the urinary bladder and adenocarcinoma of the lung. Schweizer Archiv für Tierheilkunde, 149, 314-318.

WALKER, D. B., COWELl, R. L., ClinKENBEARD, K. D. \& TURGAI, J. 1993. Carcinoma in the Urinary Bladder of a Cat: Cytologic Findings and a Review of the Literature. Veterinary Clinical Pathology, 22, 103-108.

WALLACE, M. B., KENNEDY, T., DURKALSKI, V., ELOUBEIDI, M. A., ETAMAD, R., MATSUDA, K., LEWIN, D., VELSE, A., HENNESEY, W., HAWES, R. H. \& HOFFMAN, B. J. 2001. Randomized controlled trial of EUS-guided fine needle 
aspiration techniques for the detection of malignant lymphadenopathy. Gastrointestinal Endoscopy, 54, 441-447.

WANG, K. Y., PANCIERA, D. L., AL-RUKIBAT, R. K. \& RADI, Z. A. 2004. Accuracy of ultrasound-guided fine-needle aspiration of the liver and cytologic findings in dogs and cats: 97 cases (1990-2000). Journal of the American Veterinary Medical Association, 224, 75-78.

WATSON, A. T., PENNINCK, D., KNOLL, J. S., KEATING, J. H. \& SUTHERLAND-ITH, J. 2011. Safety and Correlation of Test Results of Combined Ultrasound-Guided Fine Needle Aspiration and Needle Core Biopsy of the Canine Spleen. Veterinary Radiology \& Ultrasound, 52, 317-322.

WILSON, H. M., CHUN, R., LARSON, V. S., KURZMAN, I. D. \& VAIL, D. M. 2007. Clinical signs, treatments, and outcome in cats with transitional cell carcinoma of the urinary bladder: 20 cases (1990-2004). Journal of the American Veterinary Medical Association, 231, 101-106.

WYPIJ, J. M. 2011. Getting to the Point: Indications for Fine-needle Aspiration of Internal Organs and Bone. Topics in Companion Animal Medicine, 26, 77-85.

ZAJDELA, A., MAUBlANC, D., SCHLIENGER, P. \& HAYE, C. 1986. Cytologic diagnosis of orbital and periorbital palpable tumors using fine-needle sampling without aspiration. Diagnostic Cytopathology, 2, 17-20.

ZAMBONI, G. A., D'ONOFRIO, M., IDILI, A., MALAGÒ, R., IOZZIA, R., MANFRIN, E. \& MUCELLI, R. 2009. Ultrasound-guided percutaneous fine-needle aspiration of 545 focal pancreatic lesions. AJR. American journal of roentgenology, 193, 1691-1695. 


\section{University Library}

\section{- M M N E R VA A gateway to Melbourne's research publications}

Minerva Access is the Institutional Repository of The University of Melbourne

Author/s:

Liffman, R;Courtman, N

Title:

Fine needle aspiration of abdominal organs: a review of current recommendations for achieving a diagnostic sample

Date:

2017-11-01

Citation:

Liffman, R. \& Courtman, N. (2017). Fine needle aspiration of abdominal organs: a review of current recommendations for achieving a diagnostic sample. JOURNAL OF SMALL ANIMAL PRACTICE, 58 (11), pp.599-609. https://doi.org/10.1111/jsap.12709.

Persistent Link:

http://hdl.handle.net/11343/293221 